\title{
Modulation of CD4 T Cell Response According to Tumor Cytokine Microenvironment
}

\author{
Théo Accogli 1,2,3, Mélanie Bruchard ${ }^{1,2,3,4}$ and Frédérique Végran $1,2,3,4, *$ (D) \\ 1 Faculté des Sciences de Santé, Université Bourgogne Franche-Comté, 21000 Dijon, France; \\ theo.accogli@inserm.fr (T.A.); melanie.bruchard@u-bourgogne.fr (M.B.) \\ 2 Team "CAdIR", CRI INSERM UMR1231 “Lipids, Nutrition and Cancer", Dijon 21000, France \\ 3 LipSTIC LabEx, 21000 Dijon, France \\ 4 Centre Georges François Leclerc, 21000 Dijon, France \\ * Correspondence: frederique.vegran@inserm.fr
}

check for

updates

Citation: Accogli, T.; Bruchard, M.; Végran, F. Modulation of CD4 T Cell Response According to Tumor Cytokine Microenvironment. Cancers 2021, 13, 373. https://doi.org/ 10.3390/cancers 13030373

Academic Editor: Karen E. Pollok

Received: 15 December 2020

Accepted: 18 January 2021

Published: 20 January 2021

Publisher's Note: MDPI stays neutral with regard to jurisdictional claims in published maps and institutional affiliations.

Copyright: (c) 2021 by the authors. Licensee MDPI, Basel, Switzerland. This article is an open access article distributed under the terms and conditions of the Creative Commons Attribution (CC BY) license (https:/ / creativecommons.org/licenses/by/ $4.0 /)$.
Simple Summary: It is now accepted that CD4 T lymphocytes play an essential role in the anti-tumor response. CD4 T lymphocytes can activate and regulate several aspects of innate and adaptive immunity and participate in the rejection of tumors. Understanding the impact of the tumor, through cytokines present in the microenvironment, but also the effect of anti-cancer therapies are critical aspects of immunotherapy research aiming at improving the anti-tumor response dependent on CD4 T lymphocytes.

Abstract: The advancement of knowledge on tumor biology over the past decades has demonstrated a close link between tumor cells and cells of the immune system. In this context, cytokines have a major role because they act as intermediaries in the communication into the tumor bed. Cytokines play an important role in the homeostasis of innate and adaptive immunity. In particular, they participate in the differentiation of CD4 T lymphocytes. These cells play essential functions in the anti-tumor immune response but can also be corrupted by tumors. The differentiation of naïve CD4 T cells depends on the cytokine environment in which they are activated. Additionally, at the tumor site, their activity can also be modulated according to the cytokines of the tumor microenvironment. Thus, polarized CD4 T lymphocytes can see their phenotype evolve, demonstrating functional plasticity. Knowledge of the impact of these cytokines on the functions of CD4 T cells is currently a source of innovation, for therapeutic purposes. In this review, we discuss the impact of the major cytokines present in tumors on CD4 T cells. In addition, we summarize the main therapeutic strategies that can modulate the CD4 response through their impact on cytokine production.

Keywords: CD4; cytokines; cancer; immunotherapy

\section{Introduction}

CD4 T cells are key components of the immune system that shape the anticancer immune response in animal models but also in humans. Studies have shown that CD8 response requires CD4 "helper" functions [1-3]. At the same time, CD4 T cells can have cytotoxic activity and during adoptive transfer experiments in mice, they can induce an anti-tumor response [4]. Another study revealed that CD4 T cells can recognize neoantigens in melanoma [5]. In addition, patients who have received neoantigenic vaccines show induction of an antigen-specific CD4 T response [6,7]. The biology of CD4 T cells is complex because naive $T$ cells can differentiate into various subpopulations with different functions. Since the original classification by Mosmann and Coffman of CD4 T lymphocytes into Th1 (Thelper 1) and Th2 subsets [8], the repertoire of CD4 T cell subsets has expanded to include additional effector T cell subsets like Th17 cells [9-11], Follicular helper T cells (Tfh) [12] and Foxp3 (Forkhead box P3) regulatory T cells(Tregs) [13]. The relevance of these CD4 T 
cell subtypes has been documented in various immunopathological conditions such as inflammatory diseases and cancer [14-16]. In 2008, IL (Interleukin)-9-producing CD4 T helper cells (Th9) were identified as a new subset of CD4 Thelper cells that are proinflammatory in vivo [17,18]. IL-2 and IFN $\gamma$ (Interferon) producing CD4 T cells such as Th1 have been shown to play an essential role in the induction and persistence of anti-tumor CD8 T cells. Conversely, Tregs have a pro-tumor role through their immunosuppressive activity. Th2 and Th17 are thought to have pro-tumor functions due to the cytokines they produce $[19,20]$ but their roles are still controversial. Understanding the differentiation mechanisms of these cells, but also the impact of the tumor environment on their differentiation and activity could allow the development of innovative therapeutic strategies.

\section{Cytokine Environment of Tumors}

Cytokines are chemical mediators synthesized by different cells in an organism. They have been grouped into subsets according to the cells that produce them (monokines produced by myeloid cells, lymphokines produced by lymphocytes, interleukins produced by leukocytes, and chemokines responsible for the migration of leukocytes). They can also be classified according to their predominant role: interleukins, interferons, TNFs (Tumor Necrosis Factor), growth factors, and chemokines. Interleukins are cytokines that serve as a messenger between different immune cells. They are mainly produced during inflammatory reactions. Tumors are indeed composed of multiple cell types, including innate and adaptive immune cells that have a profound impact on tumor progression [21]. However, immune activation during tumor progression can lead to contrasting outcomes. Chronic activation of immune effector cells by tumor cells triggers the release of proinflammatory cytokines, chemokines, and other bioactive mediators, thereby creating an inflammatory milieu. This chronic inflammation, which has been observed in cases of obesity or smoking, leads to high risks of cancer [22]. In addition, recent studies show that unresolved inflammation promotes tumor progression, for example by promoting the stability of p53 mutants [23]. In contrast, the immuno-surveillance concept, initially brought up by Burnet in 1957 and later substantiated by mouse and human findings, states the immune system is capable of limiting tumor development [24]. In this context, there is a balance shift from inhibitory to activating cytokines to generate a protective anti-cancer response.

TGF $\beta$ (Transforming Growth Factor) is frequently present in the tumor microenvironment. It was initially described as a signal to prevent premalignant progression but became a factor that malignant cells use to their own advantage. The presence of these immune-infiltrating cells, known for their capacity to produce TGF $\beta$ coincides with the amount of TGF $\beta$ [25] providing additional complexity in the regulation of this cytokine.

Tissue damage occurring during tumor development and the release of alarm cytokines such as IL- $1 \alpha$, IL-1 $\beta$, and TNF $\alpha$ induce the production of IL-6, IL-10, IL-11, and IL-23 by tissues and myeloid cells. These cytokines, which allow an autoregulation loop under homeostatic conditions, will promote the proliferation of tumor cells, the healing of damaged tissues but also angiogenesis and tumor vascularization by induction of VEGF (Vascular Endothelial Growth factor) [26].

The inflammasome is a protein complex originally described in innate immune cells such as macrophages. The inflammasome sets up after the detection of so-called danger signals. A first signal (priming), generally dependent on TLR (Toll-Like Receptor) will allow the induction of NLRP3 (NOD-Like Receptor family Pyrin domain containing 3) and IL-1 $\beta$ gene expression [27]. A second signal, such as efflux of potassium following an alteration of the cell membrane, lysosomal destabilization, or even mitochondrial damage, activates the inflammasome and induces its formation. The composition of the inflammasome varies depending on the activator. The NLRP3 inflammasome is the best described. It is made up of the NLRP3 protein, ASC (Apoptosis-associated Specklike protein containing a CARD) adapter, and Caspase- 1 , which is activated when the inflammasome sets in. The Caspase- 1 once activated can participate in the maturation of 
the pro-inflammatory cytokines IL-1 $\beta$ and IL-18 [28]. Some cancer, including advanced melanoma, spontaneously release IL-1 $\beta$ [29]. IL-33 is a member of the IL-1 superfamily [30]. It is now well known to have an important role in innate and adaptive immunity through its contribution to tissue homeostasis and to stress responses such as tumor development. IL-33 is constitutively expressed at high levels in the nucleus of human and murine tissue mucosa and in various cell types, such as endothelial cells [31,32] and barrier tissue epithelial cells [32,33]. Fibroblast reticular cells of lymphoid tissues and cells of the central nervous systems represent a major source of IL-33 [32,34].

Immune cells are the main cytokine producers in tumors. IL-2 is produced mainly by CD4 T cells simulated by an antigen, but also by NK (Natural Killer) and activated dendritic cells $[35,36]$. TNF $\alpha$ is produced primarily by activated macrophages, but can also be produced by many other immune cells. IL-4, the most important Th2 cytokine, is mainly produced by activated T cells, mast cells, basophils, and eosinophils. IFN $\gamma$ is predominantly produced by NK cells in the innate arm of the immune system, as well as by effector T cells like CD4 and CD8 T cells in the adaptive arm of the immune system and could be regulated by miRNA [37,38]. Innate lymphoid cells have also been shown to produce IFN $\gamma[39,40]$. Varying degrees of IFN $\gamma$ are also secreted by mucosal epithelial cells and macrophages [41]. Regarding the cell source of IL-27, this cytokine is mainly produced by cells of myeloid origin such as monocytes, macrophages, dendritic cells, and microglial cells, in response to stimuli acting through Toll-like receptors [42] or TNF-Rfamily members, for example, CD40L [43]. Finally, IL-12 was originally identified as an NK cell-stimulatory factor with multiple biologic effects on lymphocytes [44]. It is mainly produced by APCs (Antigen Presenting Cells) and B cells upon TLR engagement [45].

\section{Impact of Cytokines from the Tumor Microenvironment on CD4 T Cells}

\subsection{Protumor Effects}

\subsubsection{TGF $\beta$}

TGF $\beta$ is a pleiotropic cytokine that acts by the engagement of a tetrameric receptor composed of the TGF $\beta$ I and II receptors. The binding of TGF $\beta$ to its receptor triggers serine/threonine kinase receptor activity, allows phosphorylation of downstream signaling targets. TGF $\beta$ signaling is primarily mediated by the SMAD family transcription factors but is also known to initiate Smad-independent pathways. The induction of Tregs peripheral differentiation is directed, among other things, by environmental stimuli such as the presence of TGF $\beta$ [46]. The key role of TGF $\beta$ in inducing Foxp3 expression in Tregs was identified by studies showing that deletion of CNS1 (Conserved Non-coding Sequence) region of Foxp3 (which contains the conserved Smad3 binding sequence) or the Smad binding site itself, results in a reduction of Tregs [47]. Moreover, the TGF $\beta$ present in the tumor microenvironment can interfere with conventional $\mathrm{T}$ cell activation by inhibiting TCR (T Cell Receptor) signaling $[48,49]$. It is also able to inhibit T helper subtypes by suppressing the expression of the transcription factors defining their profile, such as Tbet (T-box transcription factor) and Gata3, which are essential for Th1 and Th2 respectively $[50,51]$. Several works have demonstrated the redundant roles of the Smad2 and Smad3 transcription factors in the inhibition of Th1 differentiation by TGF $\beta$ [52]. The Smad signaling pathway has also been shown to induce the transcription factor SOX4 (SRY-Box Transcription Factor) which interferes with Gata3 activity during Th2 differentiation [53]. A recent study showed that the specific targeting of TGF $\beta$ signaling in CD4 T cells, via a TGFBR2 coupled to a CD4 antibody induces an anti-tumor response mediated by IL-4 in a mouse breast cancer model [54]. Finally, Th17 cells harbor ambivalent effect on cancer [55] but it seems that TGF $\beta$ could be responsible for immunosuppressive and pro-tumor functions of Th17 cells [56] (Table 1). 
Table 1. Effects of cytokines present in the tumor microenvironment on the immune response, CD4 T cells, and tumor growth.

\begin{tabular}{|c|c|c|c|c|}
\hline Cytokines & Effect on Immune Response & Associated CD4 T Cell Subsets & Effect on Tumor Growth & References \\
\hline TGF $\beta$ & Immunosuppressive & Treg, Th9 & Promotion & {$[47,50,51,56]$} \\
\hline IL-6 & Inflammatory & Th17 & Promotion & {$[57,58]$} \\
\hline IL-2 & Inflammatory & All & Ambivalent & [59-68] \\
\hline IL-1 & Inflammatory & Th17, Th9 & Ambivalent & [69-74] \\
\hline $\mathrm{TNF} \alpha$ & Inflammatory & Th1, Th17 & Ambivalent & [75-78] \\
\hline IL-23 & Inflammatory & Th17 & Ambivalent & [79] \\
\hline IL-17 & Inflammatory & Th17 & Promotion & [80] \\
\hline IL-4 & Immunosuppressive & Th2, Th9 & Ambivalent & {$[54,81,82]$} \\
\hline IL-13 & Immunosuppressive & Th2 & Promotion & [83] \\
\hline IL-33 & Immunosuppressive & Th2 & Promotion & {$[84,85]$} \\
\hline IFNs type I & Inflammatory & Th1 & Inhibition & [86-88] \\
\hline IFN type II & Inflammatory & Th1 & Inhibition & [89] \\
\hline IFN type III & Inflammatory & Th1 & Inhibition & [90-93] \\
\hline IL-12 & Inflammatory & Th1 & Inhibition & [94-96] \\
\hline IL-15 & Immunosuppressive & Th1 & Promotion & [95] \\
\hline IL-18 & Inflammatory & Th1 & Inhibition & [95] \\
\hline
\end{tabular}

\subsubsection{IL-6}

Canonical IL-6 signaling pathway depends on its IL-6R membrane receptor, which is a common receptor for IL-6, IL-11, LIF (Leukemia Inhibitory Factor), Oncostatin, cariotrophine1 , and IL-35. The homodimerization of this receptor during IL-6 binding leads to the activation of Tyrosine Kinases associated with IL-6R, JAK1 (Janus Kinase), JAK2, and TYK2 (Tyrosine Kinase) and to the phosphorylation, translocation, and activation of STAT1 (Signal Transducer and Activator of Transcription) and STAT3 [97,98]. Induction of this pathway is responsible for T cell proliferation and commitment to the Th17 and Tfh subtypes [99,100]. IL-6 blocks Foxp3 activity, limiting the ability of TGF $\beta$ to promote the development of Tregs. Thus, by participating in the Th17 differentiation, IL-6 amplifies the pro-inflammatory response $[57,58,101]$ (Figure 1 and Table 1 ).

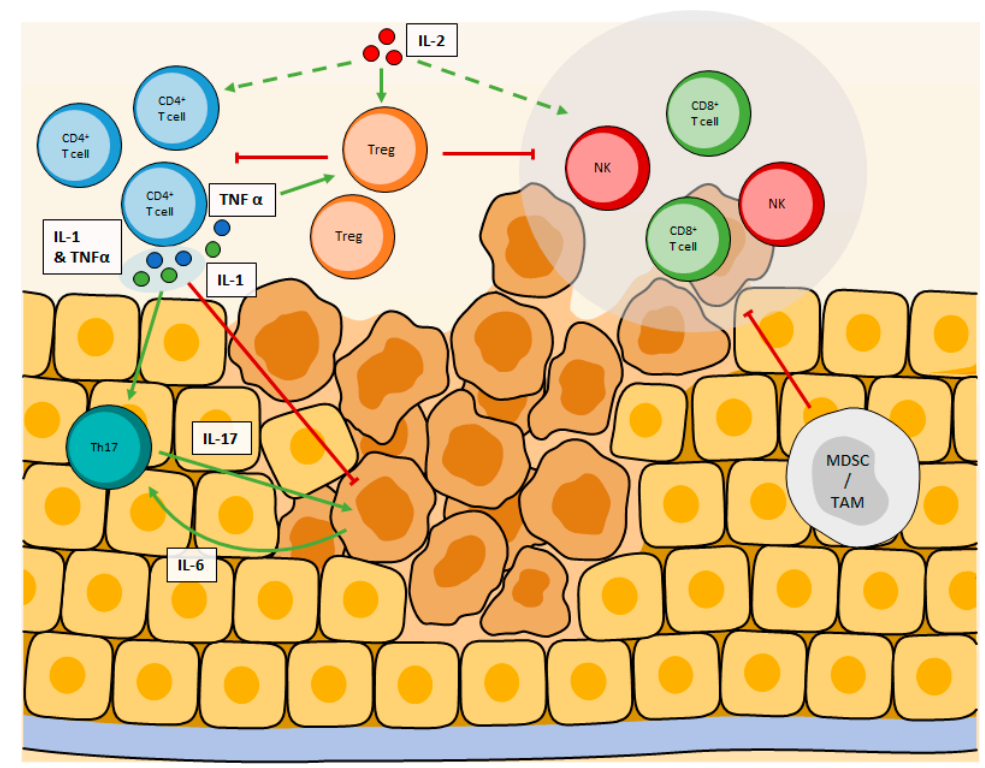

Figure 1. Ambivalent cytokines modulating $\mathrm{CD} 4^{+} \mathrm{T}$ cell responses in the tumor microenvironment. IL-2 stimulates both $\mathrm{CD}^{+}, \mathrm{CD} 8^{+}$, and NK cells but has a greater affinity for the IL2R $\alpha \beta \gamma$ expressed by Tregs. High doses of IL-2 enhance anti-tumor immune response while low doses preferentially stimulate Tregs proliferation, leading to immune suppression. Similarly, while high doses of TNF $\alpha$ and IL-1 have anti-tumor effects, in the lower amount, they both stimulate Th17 cells, plus Tregs for $\mathrm{TNF} \alpha$, leading to angiogenesis and immunosuppression, which favor tumor growth. 


\subsubsection{IL-2}

IL-2 is a key regulator of T cell survival, differentiation, and proliferation [102]. It is the most studied cytokine in the field of cancer immunotherapy [103]. Activation of the CD25 receptor (or IL-2R) by IL-2 will lead to cytosolic signaling pathways dependent on serine/threonine kinases which make it possible to initiate the activity of mTORC1 (Target Of Rapamycin Complex), which in turn modulates cell metabolism [104]. However, STAT5 is the critical mediator of IL-2 signals [105-107]. Analysis of STAT5 binding sites using Chromatin Immunoprecipitation in CD4 T cells have shown that a number of essential transcription factors defining CD4 T cells are direct STAT5 target genes. These include Foxp3 [59,60], Tbet21 [61], Maf [62], and Gata3 [63]. However, not all STAT5 binding sites are associated with increases in gene expression: binding of STAT5 to the ill7a locus is repressive, thus inhibiting STAT3-mediated transcription of the il17 gene and suppressing the differentiation into Th17 cells [64]. Likewise, STAT5 has been shown to bind to the $b c l 6$ promoter in CD4 T cells $[65,108]$, correlating with repressed expression of the gene and thus limiting the differentiation of TFh [65]. The IL-2 receptor (IL-2R) is made up of 3 subunits $\alpha, \beta, \gamma$. IL-2 has a better binding affinity with the IL-2R $\alpha \beta \gamma$ complex than with the other combinations and in particular the simple or heterodimeric IL-2R [109]. Tregs have the greatest affinity for IL-2 among T cells [102]. These cells, which prevent the development of autoimmunity under homeostatic conditions [110] have immunosuppressive and pro-tumor effects. CD4 T lymphocytes evolving in a tumor environment rich in IL-2 (in association with TGF $\beta$ ) express the transcription factor Foxp3, which impairs the differentiation of Tregs and the production of IL-10, that participate in an immunosuppressive microenvironment [66-68]. In this context, Tregs are capable of suppressing the anti-tumor functions of CD4, CD8, and NK cells, leading to an absence of effective anti-tumor immune response (Figure 1 and Table 1).

\subsubsection{IL-1}

IL-1 $\beta$ is undoubtedly a cytokine with an ambivalent role. Indeed, the IL- $1 \beta$ secreted in the tumor microenvironment induces the secretion of IL-17 through its effect on CD4 T cells, by driving the differentiation and expansion of Th17 cells, which promote angiogenesis and tumor growth via the STAT3 signaling pathway $[69,80]$. IL-17 also recruits MDSCs, exhibiting major immunosuppressive activity [70,71]. Conversely, for several years, studies have shown that IL-1 $\beta$ can participate in the eradication of tumors. Indeed, it is one of the cytokines constantly associated with the effective eradication of cancer by a Th1 response, in particular in myeloma and B lymphoma [72]. In this study, the authors propose that IL-1 $\alpha$ and $\beta$ could promote tumor progression, but in association with other cytokines, in particular, those signaling a Th1 response and their effects on macrophages, they rather promote an anti-tumor immune response. In another study, a team confirmed that IL- $1 \alpha$ and $\beta$ are essential for a complete Th1- induced anti-tumor response in melanoma [73]. Th9 cells are closely related to the Th2 lineage, which generally antagonizes Th1 responses. However, Th9 cells and their anti-tumor cytokine IL-9 are powerful anti-tumor agents, which can be exploited in cell therapy [111]. Typically induced by IL-4 and TGF $\beta$, the absence of the latter could be replaced by IL-1 $\beta$ to promote Th9 cells [112]. Moreover, Th9 cells differentiated in presence of TGF $\beta$ and IL-4 harbor higher anti-tumor activity when IL-1 $\beta$ is present [74] (Table 1). In short, it seems that the concentration of IL-1 is the key to understand its effects on tumor growth. While a low concentration would trigger protumor events in the tumor microenvironment and stimulate tumor growth, metastasis, and angiogenesis, high doses of IL-1 promote anti-tumor responses. However, it is necessary to keep in mind that high concentrations of IL-1 can have serious toxic effects [113] (Figure 1).

\subsubsection{TFN $\alpha$}

TNF $\alpha$ is a powerful anti-tumor cytokine. TNF $\alpha$ was identified in 1975 and named after its ability to induce necrosis of mice sarcomas when injected at high concentrations [75]. Signaling cascades induced by its binding to one of its receptors (TNFR1, TNFR2) induce 
cell death by necrosis or apoptosis. This is why TFN $\alpha$ was one of the first cytokines clinically used for the treatment of cancer [114]. Concerning T cells, TNF $\alpha$ appears to be one of the weapons of antigen-specific CD8 T cells to eradicate tumor cells [76]. To focus on CD4, a recent study used CD4 $\mathrm{T}$ cell-based adoptive immunotherapy to treat CT26 colorectal tumors. The authors show that antigen-specific CD4 T cells can eradicate established CT26 tumors when injected after cyclophosphamide treatment. This is achieved through cytokinemediated CD4 response, and mostly via $\mathrm{TNF} \alpha$, which synergize with chemotherapy to induce ROS (Reactive Oxygen Species) in CT26 cells [115]. The authors also mention that IFN $\gamma$ may be necessary and that the efficacy of $\mathrm{T}$ cells to achieve a complete eradication may rely on the concomitant secretion of both IFN $\gamma$ and TNF $\alpha$. Still, the anti-tumor effects of TNF $\alpha$ require greater concentrations than cells can physiologically produce within the tumor. Unexpectedly from a cytokine called after its ability to induce cancer cell death, pro-tumor effects of TNF $\alpha$ have also been reported. Indeed, TNF $\alpha$ deficient mice as well as TNFR1 or TNFR2 deficient mice are resistant to skin tumor development [116]. The mechanisms underlying this may imply CD4 T cells. Indeed, although considered to be an anti-tumor factor at high concentrations [117], TNF $\alpha$ exhibits a deleterious effect due to its ability to stimulate regulatory CD4 T cells. Several studies carried out in vitro using mouse material show an increase in the proliferation, survival, stability, expression of CD25 and Foxp3, as well as an increase in the immunosuppressive functions of Tregs, treated with TNF $\alpha[77,78,118,119]$ (Table 1). Tregs from human blood all express high levels of TNFR2 while other CD4 T cells express lower levels of this receptor [120]. Likewise, in mice, more than 90\% of Foxp3+ cells present in peripheral lymphoid organs express TNFR2 [77]. Indeed, to secrete IL-17A and recruit myeloid cells into the tumor in a mouse ovarian cancer model, CD4 T cells needs the expression of TNFR1 [121]. In addition, TNFR2 seems to be upstream of a pathway that favors Tregs proliferation within the tumor [122] leading again to promote tumor growth. If stromal cells are the main source of TNF $\alpha$ within the tumor, CD4 T cells also produce TNF $\alpha$ in sufficient amount to inhibit CD8 T cells anti-tumor response but insufficient to impact tumor cells proliferation or viability [123]. Here again, the tipping point between pro and anti-tumor TNF $\alpha$ effects relies on its concentration. While high concentrations will trigger tumor cell death mechanisms, low doses activate pathways that sustain tumor growth (Figure 1).

\subsubsection{Other Cytokines with Immunosuppressive Effect}

IL-23 is a cytokine of the IL-12 family. It is an interleukin produced in response to DAMPS (Damage Associated Molecular Pattern) at the level of epithelial barriers [124]. IL-23 is present in the tumor microenvironment and triggers the production of IL-17 during Th17 differentiation in synergy with IL-6. It also contributes to the amplification of inflammation [124,125] and could be used in therapeutic strategies [79] (Figure 1 and Table 1).

Tumor cells may secrete factors to promote Th2 and TAM2 (Tumor-Associated Macrophage) polarization, which in turn amplify this type of inflammation via IL-4, IL-5 and IL-13, suppress anti-tumor Th1 polarization and responses [126], and correlate with MDSC infiltrates [83]. Nevertheless, IL-4 was recently described to have anti-tumor functions through angiogenic-dependent properties [54,81]. Besides its role in creating a macrophagedependent tumorigenic niche, IL-33 may directly promote TGF $\beta$ elicited Tregs differentiation, suppress IFN $\gamma$, and promote Tregs stability in the tumor [84,85] (Table 1).

\subsection{Antitumor Effects}

IFNs are classified into three different types, numbered from I to III. The type I family consists of 18 members that all bind to the same heterodimer receptor composed of IFN$\alpha / \beta$ receptor 1 and 2 . IFN- $\alpha$ and IFN- $\beta$ are the most studied type I interferons and some anticancer treatment efficacy depends on their effects on the tumor microenvironment [86]. Mainly produced by DCs within the tumor and the tumor-draining lymph nodes, these cytokines can modulate lymphocyte responses. They are notably associated with tumorspecific CD8 T cell activation [127-129]. Regarding CD4 T cells, IFN- $\alpha$ is associated with 
enhanced activation of $\mathrm{CD}^{+} \mathrm{T}$ cells [87] as well as a reduced frequency of Tregs within the tumor microenvironment [88] (Table 1). On the other hand, recent studies demonstrate that type I IFNs could protect cancer cells from CTLs (Cytotoxic T lymphocytes) [130]. They could be deleterious for CD4 and CD8 CAR-T (Chimeric Antigen Receptor) cells viability and it was proposed to render CAR-T insensitive to IFN I to avoid this inhibitory effect [131]. The type II family only consists of IFN- $\gamma$, which is also well studied in a cancer context [89]. Type III interferons, or interferons lambda, are the most recently discovered IFN. Structurally similar to type II IFN, their activity resembles the one of type I IFN [90]. Type III IFN are typically produced in response to viruses or bacteria and type 2 myeloid dendritic cells that have been described to be the main producer of IFN- $\lambda$ [132]. IFN- $\lambda$ inhibits growth and induces apoptosis of cancer cells in models of lung, liver, prostate, and breast cancer [90-93] (Table 1). T cells and NK display increased anti-tumor responses against various cancer models including melanoma, breast, and lung in the presence of IFN- $\lambda$ [90]. However, this effect is most likely indirect as T cells express an extremely low amount of its receptor [133]. Its receptor, IFNLR1, is indeed expressed by few cell types and since IFN- $\lambda$ has shown anti-tumor properties, it represents a great potential as an anti-cancer therapy with diminished side effects, compared to other IFN.

IL-12, derived from dendritic cells, provides an essential signal, which drives the expression of Tbet, and therefore the differentiation of Th1 effector cells [94-96] (Table 1). In addition, IL-2, IL-15, and IL-18 synergize with IL-12 to trigger the production of IFN $\gamma$ and direct cytotoxicity of Th1 cells $[67,95]$ (Table 1).

\section{Effects of Diverse Treatments on CD4 T Cell Response}

\subsection{Cytokine Based Therapies}

The first tests using recombinant interleukins have encountered severe toxicities problems, even leading to the death of patients. Nevertheless, many of these trials have shown immune responses during treatment, providing a proof of concept for interleukins therapy in cancer.

The first cytokine-based therapy against cancer ever administered used IL-2 but its use involves security concerns [103]. IL-2 is a pleiotropic cytokine produced mainly by $\mathrm{T}$ lymphocytes. It is essential for the survival of lymphocytes and plays an important role in the initiation and maintenance of antigen-specific immune responses. Promising pre-clinical evidence were obtained in several models using IL-2 based therapy with their efficacy being a consequence of $\mathrm{T}$ lymphocytes expansion and increase in effector functions. The high dose IL-2 regimens are very toxic and recent advances focus on modifying it to reduce toxicity and could help overcome this problem. On the other hand, low dose IL-2 regimens have been evaluated in several trials. However, in low abundance, IL-2 binds preferably to its high-affinity IL-2R $\alpha \beta \gamma$ receptor expressed on Tregs leading to their induction, thus preserving an immunosuppressive milieu in tumors [134]. Thus, a major concern about IL-2 therapy is the induction of Tregs via IL-2Ra (CD25). Several variants of IL-2 with an affinity towards the other IL-2R complex expressed by cytotoxic T cells are under development [135-137]. Some of these have an altered IL-2R $\alpha$ binding domain, to alter the induction of Tregs immunosuppressive responses while maintaining effector $\mathrm{T}$ cells and NK cells immune responses, like the F42A mutant [138], but it may also affect CTLs. A next-generation IL-2 is now studied to overcome all IL-2 defects: tumor targeting, toxicity, half-life, and CTLs preferential binding but not Tregs. In a recent study, Zinchen Sun and colleagues have shown the efficacy in mice of an IL-2 with several mutations to favor its affinity to CD122 and fusion with an IgG1 Fc fragment to increase its half-life and an anti-EGFR (Epidermal Growth factor-Receptor) to preferentially target the tumor [139]. This next-generation may be a new hope for IL-2 based treatments.

Years later, IL-21 became the new focus of cytokine-based therapy. IL-21 is a cytokine produced by activated CD4 T lymphocytes and its receptor is found on many populations of lymphocytes. It is known to stimulate Tfh, cytotoxic T lymphocytes, and NK cell proliferation and functions. IL-21 is essential for the differentiation of Tfh through its 
induction of two key transcription factors for Tfh: Bcl6 (B-cell lymphoma 6 protein) and Maf. Differentiated Tfh can subsequently produce IL-21 to stimulate B cells and the creation of a robust B cell response. IL-21 also exerts its anti-tumor effects via its stimulation of NK cells and CTL [140], two anti-tumor immune populations. However, IL-21 based therapy showed antitumor effects when associated with other treatments like checkpoint inhibitors [141] or DNA vaccines [142]. Several clinical trials using IL-21 have now been conducted in humans, alone or in combination, with the restraining aspect of a dose limitation due to toxicities (such as neutropenia or thrombocytopenia) (Figure 2).

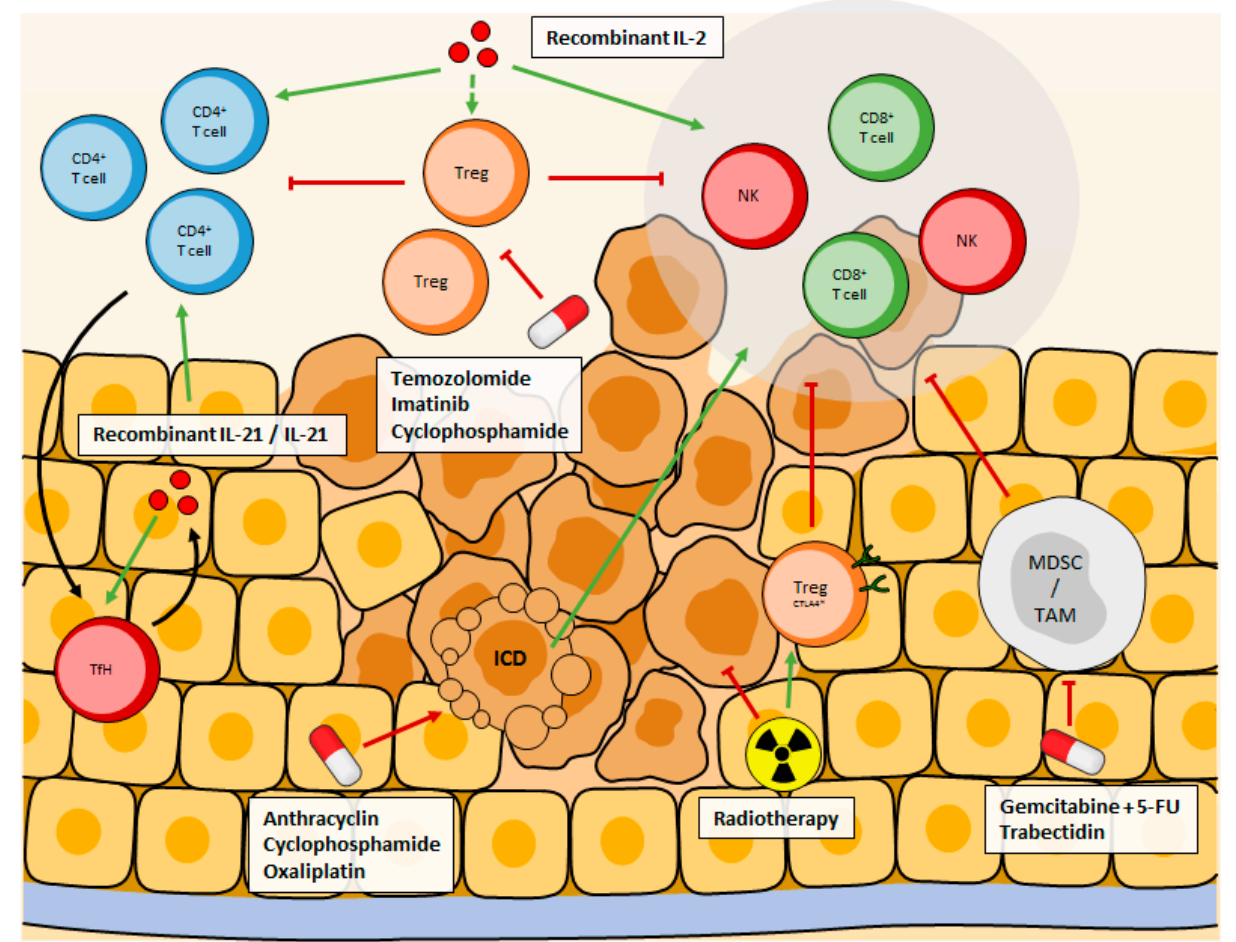

Figure 2. Recombinant IL-2 is designed to preferentially bind to IL2R $\alpha$ or IL2R $\beta \gamma$ to avoid Tregs expansion, while stimulating $\mathrm{CD}^{+}, \mathrm{CD}^{+}{ }^{+}$, and NK cells. Recombinant IL-21 also stimulates CD4 ${ }^{+}$, $\mathrm{CD}^{+}$, and NK cells as well as TFh cells, creating an auto-amplification loop. Some treatments inhibit Treg cells, MDSCs or TAM, to remove the immunosuppression they exert, while others indirectly promote anti-tumor immune response through immunogenic cell death. Radiotherapy is a doubleedged sword, it directly kills tumor cells, but post-treatment it favors the recruitment of Tregs that highly express CTLA4, resulting in enhanced immune-suppression.

\subsection{Therapeutic Neutralization}

Canakinumab, an IL-1 $\beta$ blocking antibody, is being studied as monotherapy and in combination in several types of cancer. Several trials on lung cancer, breast cancer, colorectal cancer, pancreatic cancer, renal cancer, and melanoma emphasize the interest in blocking IL-1 $\beta$. For example, in 2018, a phase 3 trial of Canakinumab compared to placebo began in Non-Small Cell Lung Cancer (NCT03447769). Likewise, a phase 2 trial studying Canakinumab as monotherapy for myelodysplastic syndrome and chronic myelogenous leukemia was launched in 2020. In 2018, a phase 3 trial using Canakinumab in combination with Pembrolizumab and chemotherapy in Non-Small Cell Lung Cancer was also launched (NCT03631199) and in 2019 another one started (NCT03626545).

Anakinra is an unglycosylated form of human IL-1RA that competitively inhibits IL-1 $\alpha$ and IL-1 $\beta$ from binding their receptor [143]. It has shown benefits in several clinical trials. A phase 2 trial of Anakinra in combination with dexamethasone in patients with smoldering and indolent multiple myeloma has shown increased survival of responders compared to non-responders $[144,145]$. Anakinra is also under investigation in several other 
clinical trials in pancreas carcinomas, triple-negative breast cancers, colorectal cancers, and melanoma. A phase 2 clinical study shows that the use of Anakinra restored the antitumor efficacy of 5-FU (5-FluoroUracil) in patients. Of the 32 patients enrolled, 5 presented a response (CHOI criteria) and 22 patients had a stable disease [146]. Another possible candidate is Rilonacept, the extracellular domain of IL-1RAcP (Interleukin-1 Receptor Accessory Protein) and IL-1R1 fused to the Fc part of human IgG1. It has a strong affinity with IL-1 $\beta$ and IL-1 $\alpha$, and strongly inhibits the activity of IL-1 [147]. However, these blockers inhibit both IL- $1 \beta$ and IL- $1 \alpha$, but IL- $1 \alpha$ may have synergistic or antagonistic effects, depending on the context.

Another interleukin associated with tumorigenesis, and therefore an attractive target for immunotherapy, is IL-6. The anti-IL-6 antibody Siltuximab has been studied in cancer patients. Although it has been approved by the Food and Drug Administration (FDA) for Unicentric Castleman's disease in 2014, its efficacy has not been proven in solid tumors. In prostate cancer and treatment of colorectal cancer, the best outcome was stable disease $[148,149]$. In combination with chemotherapy, the anti-IL-6R antibody Tocilizumab gave the first positive results in epithelial ovarian cancer and immunological response such as an increase in T lymphocyte activation has been observed [150] (Figure 2).

\subsection{Treatments Targeting Regulatory T Lymphocytes}

Regulatory T lymphocytes (Tregs) are an important immunosuppressive population, commonly found in tumors. One strategy to restore immune responses against a tumor is to get rid of these immunosuppressive cells. The study of the impact of chemotherapies on the immune system showed that several molecules were capable of targeting Tregs, like Cyclophosphamide [151], Paclitaxel [152], Temozolomide [153], and Imatinib [154].

Cyclophosphamide is a chemotherapy commonly used against neuroblastoma, sarcoma, and ovarian cancer amongst others. A low dose of cyclophosphamide $\left(<300 \mathrm{mg} / \mathrm{m}^{2}\right)$ is responsible for a decline in Tregs as observed in both humans and mice. The specificity of cyclophosphamide for Tregs is thought to be due to lower levels of ATP present in Tregs as compared with other T cells. This low level of ATP results in low levels of glutathione in Tregs that are consequently less efficient in detoxifying Cyclophosphamide [155]. However, this antitumor effect of Cyclophosphamide against Tregs is to be balanced by its capacity in mice and cancer patients to promote the differentiation of Th17 [156]. The role of Th17 is ambiguous, mainly depending on the cytokines present in the tumor alongside the Th17 so the promotion of its differentiation can have both positive and negative effects depending on the context [56].

Imatinib mesylate is a tyrosine kinase inhibitor of the oncogenic BCR-ABL protein (found in Philadelphia chromosome-positive chronic myeloid leukemia), KIT and platelets derived growth factor receptor- $\alpha$. Imatinib has been described to inhibit Tregs activity by reducing FoxP3 expression [154]. In a model of the gastrointestinal stromal tumor, Imatinib induced Tregs apoptosis in the tumor bed by reducing the tumor expression of the immunosuppressive enzyme Indoleamine 2,3-DiOxygenase (IDO). Association with immunotherapy further improved imatinib efficiency against the tumor [157]. In patients with chronic myelogenous leukemia, imatinib-treated patients exhibited selective depletion of Tregs and a significant increase in effector/memory CD8 T cells [158].

Paclitaxel is a chemotherapeutic agent used in the treatment of various tumors like breast cancer, ovarian cancer, or lung cancer. Paclitaxel can reduce the expression of FoxP3, a master regulator of Tregs, associated with reduced inhibitory functions of these cells [159]. In patients with cervical cancer, paclitaxel was shown to induce a significant decrease in Tregs associated with increased rates of cytotoxic CD8 T cells in the tumor stroma [160].

Temozolomide is an alkylating agent known to prolong survival in patients with high-grade glioma, glioblastoma, and melanoma [161]. Temozolomide is responsible for a profound lymphopenia, including Tregs in humans but seems more specific to Tregs in mice [162] (Figure 2). 


\subsection{Immune Checkpoint Inhibitors}

The identification of immune checkpoints blocking lymphocyte functions has led to the emergence of new strategies aiming at the reactivation of those lymphocytes. Immune checkpoints can be expressed by lymphocytes (PD-1, CTLA-4, TIGIT, TIM-3 ... ) with their ligands found on tumor cells, DCs (Dendritic Cell), and APCs. Lymphocyte populations found within the tumor bed harbor higher levels of immune checkpoint expression than in their healthy counterparts and are thus less active against the tumor. Lifting the immune checkpoints dependent immunosuppression allows the return of an anti-tumor immune response. Immune checkpoint inhibitors (ICIs), consisting of blocking antibodies targeting PD-1, PD-L1, and CTLA-4, have been the first ones to be authorized as anti-cancer therapies. Pembrolizumab and Nivolumab (anti-PD-1) showed promising results in melanoma patients as well as in non-small cell lung carcinoma patients with an objective response rate of about 45\% [163-165]. Ipilimumab (anti-CTLA-4) is used against advanced melanoma but is often responsible for immune-related side effects [166]. It is now more commonly found associated with other treatments. Atezolizumab, Durvalumab, and Avelumab are antibodies targeting PD-L1. Anti-PD-L1 antibodies are used against urothelial cancers [167], NSCLC [168], small cell lung cancer [169], kidney cancer [170], or triple-negative breast cancer [171] and show promising results, often associated with other molecules. The percentage of patients responding to ICIs varies considerably between cancers. For instance, only $19 \%$ of triple-negative breast cancer patients responded to anti-PD-1 [172] when $87 \%$ of patients with relapsed or refractory Hodgkin's lymphoma presented an objective response to anti-PD-1 [173]. The Association of Ipilimumab and Nivolumab in treating patients is rising as observed by the many ongoing phase II and III clinical trials. These trials concern patients with advanced kidney cancer (NCT03793166, NCT04510597), advanced melanoma (NCT02339571, NCT04511013), Hodgkin lymphoma (NCT01896999, NCT02408861), glioblastoma (NCT04396860, NCT04145115), and many other cancers. Association of Ipilimumab and nivolumab has been approved by the US FDA in NSCLC patients with a PD-L1 expression $\geq 1 \%$ and seems to a higher survival rate in patients with PD-L1 $\geq 50 \%$ when compared to platinum-based chemotherapy but its effects on progression-free survival or overall response remains to be determined [174]. On average, however, only about $20-25 \%$ of patients respond to ICIs alone. This can probably be explained by the weak infiltration of lymphocytes within the tumor in many cancers and is the reason why ICIs are often combined with other treatments [175]. Interestingly, the tumor mutation burden is a potential predictive biomarker regarding the likelihood of a tumor to respond to ICIs [176]. Checkpoint inhibitors are now used as single agents or combined with chemotherapies in about 50 cancer types. ICIs do not target one lymphocyte specifically but rather will affect all lymphocytes bearing its target (Figure 2).

\subsection{Chemotherapy}

Gemcitabine and 5-FU are two nucleoside analogs known to suppress MDSCs in several murine tumor models $[177,178]$. This suppression of MDSCs results in a reduced tumor growth dependent on T cells. These effects are however transient as dying MDSCs release IL- $1 \beta$ that increase IL-17 producing CD4 T cells, establishing another form of immunosuppression [69]. The association of anti-IL-1 $\beta$ with a 5-FU treatment was able to lead to full recovery in about $40 \%$ of mice. A phase 3 clinical trial is currently ongoing in colorectal cancer patients [146]. Doxorubicin can also target MDSC [179]. In a murine mammary cancer model, doxorubicin led to the reduction of MDSC frequencies in the spleen. This depletion allowed an increase in Granzyme B and IFN- $\gamma$ production by effector T cells and NK cells.

Tumor-associated macrophages can be depleted using trabectedin [180], a treatment used in the treatment of advanced soft tissue sarcoma and ovarian cancer relapses. Trabectedin depletes TAM in a range from 30 to $77 \%$ observed in clinical studies through the induction of apoptosis. A molecule similar to Trabectidin, Lurbinectedin is also capable of reducing the TAM population in the treatment of small-cell lung cancer patients, alone or 
in association with chemotherapies or CKI [181,182]. Other molecules, such as antibodies targeting CSF1R (Colony Stimulating Factor 1 Receptor) or liposome clodronate can also efficiently deplete TAM $[183,184]$. Polarizing TAM into the anti-tumor M1 phenotype is another strategy. Paclitaxel [185], Docetaxel [186], or a combination of chemotherapies (cyclophosphamide, doxorubicin, Vincristine) favor the polarization of TAM into the M1 phenotype, resulting in an increased lymphocyte response against the tumor as observed by delayed tumor growth kinetics [187].

Cytokines such as IFN $\gamma$ or TNF $\alpha$ play crucial roles in the anti-tumor immune response. While some cancer treatments cause apoptotic cell death that is a silent cell death that does not induce an immune response, others such as anthracyclines can affect the death of cancer cells and activate the immune system. This type of cell death is called ICD (Immunogenic Cell Death). Cytokines produced during ICD may be pro-inflammatory such as TNF, IL-6, IL-8, or IL-1 $\beta$. They will induce the expression of Class I MHC (Major Histocompatibility Complex) on APCs and promote T cell differentiation [188-191]. The cytokinic response induced by ICD is essential for promoting anticancer immunity involving CD4 T cells and an increase in IFN $\gamma$ production by Th1 and IL-17 produced by Th17 is observed [192] (Figure 2).

\subsection{Radiotherapy}

If radiotherapy is commonly used in association with other treatments (surgery, chemotherapy, or immunotherapy more recently), it also influences the immune response on its own in tumors. Radiotherapy is responsible for an increase in Tregs [193] and it was later suggested that Tregs were more resistant to radiotherapy than other lymphocytes [194]. Radiotherapy increases tumor-infiltrated Tregs that express higher levels of CTLA-4 compared to Tregs from non-irradiated tumors [195], setting an immunosuppressive environment. The TGF $\beta$ production driven by radiation sustains the expression of FoxP3 in Tregs [195] but the association of radiation and immunotherapy against CTLA-4 resulted in long-term survival in a murine glioma model [196].

Interestingly, decreased percentages of Tregs were found in the peripheral blood of patients and a murine lung cancer model after radiotherapy [197]. A consensus is yet to be reached regarding the impact of radiotherapy on Tregs. Radiation dose, the scheme of treatment, tumor types are all variables that can influence the effect of radiotherapy on Treg and need to be taken into account (Figure 2).

\section{Conclusions}

Cytokines are key elements that orchestrate the tumor microenvironment. With a growing understanding of cancer biology and infiltrating immune cells such as CD4 T cells, the relevance of these cytokines and their functions, additional roles are likely to emerge.

Data concerning the role of a particular cytokine on CD4 T cells must be put in context, regarding the development of the tumor. Indeed, a cytokine can have an anti-tumor role at the beginning of carcinogenesis and harbor pro-tumor activity later on with the adaptation of the tumor and the impact of intra-tumor cytokines on the activity of CD4 T lymphocytes. Likewise, several cytokines exhibit antagonistic effects depending on their concentration depending on their effect on CD4 T cells among other things. These different elements must be taken into consideration before developing therapeutic strategies.

Similarly, it is important to note that the tumor environment is complex and that cytokines never evolve alone but always in concert. Thus, the effect of a therapy that would induce or conversely inhibit the effect of a cytokine can be partially prevented or even reversed depending on the cytokine milieu in the tumor microenvironment.

Cancer treatments by strategies modulating interleukins are quite complicated and require improvement to increase efficacy and decrease side effects. Recent therapeutic developments have shown that the neutralization of key pathways may have therapeutic activity in cancer patients by restoring the anti-tumor activity of CD4 T cells. For several candidates mentioned in this overview, the ongoing trials will reveal their efficacy and safety in randomized controlled settings. In line with the importance of cytokines, it is 
now clear that virtually all cancer treatments will modify the cytokine milieu, sometimes at the detriment of the treatment's efficacy against cancer. Moreover, these treatments are nowadays associated with other therapies to treat patients. In particular, associations with immunotherapies such as immune checkpoint inhibitors are currently under scrutiny in various cancers, both in mice and humans. A complete understanding of the consequences of treatment on the intra-tumor cytokines would allow the establishment of more precise and efficient combinations of treatments, allowing modulation of CD4 T cells activity and increasing their effectiveness.

Funding: This research received no external funding.

Data Availability Statement: Not applicable.

Conflicts of Interest: The authors declare no conflict of interest.

\section{References}

1. Janssen, E.M.; Lemmens, E.E.; Wolfe, T.; Christen, U.; von Herrath, M.G.; Schoenberger, S.P. CD4+ T cells are required for secondary expansion and memory in CD8+ T lymphocytes. Nature 2003, 421, 852-856. [CrossRef] [PubMed]

2. Sun, J.C.; Bevan, M.J. Defective CD8 T cell memory following acute infection without CD4 T cell help. Science 2003, 300, 339-342. [CrossRef]

3. Shedlock, D.J.; Shen, H. Requirement for CD4 T cell help in generating functional CD8 T cell memory. Science 2003, 300, 337-339. [CrossRef] [PubMed]

4. Quezada, S.A.; Simpson, T.R.; Peggs, K.S.; Merghoub, T.; Vider, J.; Fan, X.; Blasberg, R.; Yagita, H.; Muranski, P.; Antony, P.A.; et al. Tumor-reactive CD4(+) T cells develop cytotoxic activity and eradicate large established melanoma after transfer into lymphopenic hosts. J. Exp. Med. 2010, 207, 637-650. [CrossRef] [PubMed]

5. Linnemann, C.; van Buuren, M.M.; Bies, L.; Verdegaal, E.M.; Schotte, R.; Calis, J.J.; Behjati, S.; Velds, A.; Hilkmann, H.; Atmioui, D.E.; et al. High-throughput epitope discovery reveals frequent recognition of neo-antigens by CD4+ T cells in human melanoma. Nat. Med. 2015, 21, 81-85. [CrossRef] [PubMed]

6. Ott, P.A.; Hu, Z.; Keskin, D.B.; Shukla, S.A.; Sun, J.; Bozym, D.J.; Zhang, W.; Luoma, A.; Giobbie-Hurder, A.; Peter, L.; et al. An immunogenic personal neoantigen vaccine for patients with melanoma. Nature 2017, 547, 217-221. [CrossRef] [PubMed]

7. Sahin, U.; Derhovanessian, E.; Miller, M.; Kloke, B.P.; Simon, P.; Lower, M.; Bukur, V.; Tadmor, A.D.; Luxemburger, U.; Schrors, B.; et al. Personalized RNA mutanome vaccines mobilize poly-specific therapeutic immunity against cancer. Nature 2017, 547, 222-226. [CrossRef]

8. Mosmann, T.R.; Cherwinski, H.; Bond, M.W.; Giedlin, M.A.; Coffman, R.L. Two types of murine helper T cell clone. I. Definition according to profiles of lymphokine activities and secreted proteins. J. Immunol. 1986, 136, 2348-2357.

9. Veldhoen, M.; Hocking, R.J.; Atkins, C.J.; Locksley, R.M.; Stockinger, B. TGFbeta in the context of an inflammatory cytokine milieu supports de novo differentiation of IL-17-producing T cells. Immunity 2006, 24, 179-189. [CrossRef]

10. Mangan, P.R.; Harrington, L.E.; O'Quinn, D.B.; Helms, W.S.; Bullard, D.C.; Elson, C.O.; Hatton, R.D.; Wahl, S.M.; Schoeb, T.R.; Weaver, C.T. Transforming growth factor-beta induces development of the T(H)17 lineage. Nature 2006, 441, 231-234. [CrossRef]

11. Bettelli, E.; Carrier, Y.; Gao, W.; Korn, T.; Strom, T.B.; Oukka, M.; Weiner, H.L.; Kuchroo, V.K. Reciprocal developmental pathways for the generation of pathogenic effector TH17 and regulatory T cells. Nature 2006, 441, 235-238. [CrossRef] [PubMed]

12. Schaerli, P.; Willimann, K.; Lang, A.B.; Lipp, M.; Loetscher, P.; Moser, B. CXC chemokine receptor 5 expression defines follicular homing T cells with B cell helper function. J. Exp. Med. 2000, 192, 1553-1562. [CrossRef] [PubMed]

13. Kumar, V.; Stellrecht, K.; Sercarz, E. Inactivation of T cell receptor peptide-specific CD4 regulatory T cells induces chronic experimental autoimmune encephalomyelitis (EAE). J. Exp. Med. 1996, 184, 1609-1617. [CrossRef] [PubMed]

14. Crotty, S. Follicular helper CD4 T cells (TFH). Annu. Rev. Immunol. 2011, 29, 621-663. [CrossRef]

15. Sakaguchi, S.; Miyara, M.; Costantino, C.M.; Hafler, D.A. FOXP3+ regulatory T cells in the human immune system. Nat. Rev. Immunol. 2010, 10, 490-500. [CrossRef]

16. Korn, T.; Bettelli, E.; Oukka, M.; Kuchroo, V.K. IL-17 and Th17 Cells. Annu. Rev. Immunol. 2009, 27, 485-517. [CrossRef]

17. Dardalhon, V.; Awasthi, A.; Kwon, H.; Galileos, G.; Gao, W.; Sobel, R.A.; Mitsdoerffer, M.; Strom, T.B.; Elyaman, W.; Ho, I.C.; et al. IL-4 inhibits TGF-beta-induced Foxp3+ T cells and, together with TGF-beta, generates IL-9+ IL-10+ Foxp3(-) effector T cells. Nat. Immunol. 2008, 9, 1347-1355. [CrossRef]

18. Veldhoen, M.; Uyttenhove, C.; van Snick, J.; Helmby, H.; Westendorf, A.; Buer, J.; Martin, B.; Wilhelm, C.; Stockinger, B. Transforming growth factor-beta 'reprograms' the differentiation of T helper 2 cells and promotes an interleukin 9-producing subset. Nat. Immunol. 2008, 9, 1341-1346. [CrossRef]

19. Bankaitis, K.V.; Fingleton, B. Targeting IL4/IL4R for the treatment of epithelial cancer metastasis. Clin. Exp. Metastasis 2015, 32, 847-856. [CrossRef]

20. Wang, K. Targeting IL-17 for cancer-associated inflammation and immunity. J. Immunol. 2017, 198, 66-5. 
21. Gajewski, T.F.; Schreiber, H.; Fu, Y.X. Innate and adaptive immune cells in the tumor microenvironment. Nat. Immunol. 2013, 14, 1014-1022. [CrossRef] [PubMed]

22. Howe, L.R.; Subbaramaiah, K.; Hudis, C.A.; Dannenberg, A.J. Molecular pathways: Adipose inflammation as a mediator of obesity-associated cancer. Clin. Cancer Res. Off. J. Am. Assoc. Cancer Res. 2013, 19, 6074-6083. [CrossRef] [PubMed]

23. D'Orazi, G.; Cordani, M.; Cirone, M. Oncogenic pathways activated by pro-inflammatory cytokines promote mutant p53 stability: Clue for novel anticancer therapies. Cell Mol. Life Sci. 2020, 1-8. [CrossRef] [PubMed]

24. Chang, R.B.; Beatty, G.L. The interplay between innate and adaptive immunity in cancer shapes the productivity of cancer immunosurveillance. J. Leukoc. Biol. 2020, 108, 363-376. [CrossRef] [PubMed]

25. Massague, J. TGFbeta in Cancer. Cell 2008, 134, 215-230. [CrossRef]

26. Maloney, J.P.; Gao, L. Proinflammatory Cytokines Increase Vascular Endothelial Growth Factor Expression in Alveolar Epithelial Cells. Mediat. Inflamm. 2015, 2015, 387842. [CrossRef]

27. Bauernfeind, F.G.; Horvath, G.; Stutz, A.; Alnemri, E.S.; MacDonald, K.; Speert, D.; Fernandes-Alnemri, T.; Wu, J.; Monks, B.G.; Fitzgerald, K.A.; et al. Cutting edge: NF-kappaB activating pattern recognition and cytokine receptors license NLRP3 inflammasome activation by regulating NLRP3 expression. J. Immunol. 2009, 183, 787-791. [CrossRef]

28. Weber, A.N.R.; Bittner, Z.A.; Shankar, S.; Liu, X.; Chang, T.H.; Jin, T.; Tapia-Abellan, A. Recent insights into the regulatory networks of NLRP3 inflammasome activation. J. Cell Sci. 2020, 133, jcs248344. [CrossRef]

29. Okamoto, M.; Liu, W.; Luo, Y.; Tanaka, A.; Cai, X.; Norris, D.A.; Dinarello, C.A.; Fujita, M. Constitutively active inflammasome in human melanoma cells mediating autoinflammation via caspase-1 processing and secretion of interleukin-1beta. J. Biol. Chem. 2010, 285, 6477-6488. [CrossRef]

30. Schmitz, J.; Owyang, A.; Oldham, E.; Song, Y.; Murphy, E.; McClanahan, T.K.; Zurawski, G.; Moshrefi, M.; Qin, J.; Li, X.; et al. IL-33, an interleukin-1-like cytokine that signals via the IL-1 receptor-related protein ST2 and induces T helper type 2-associated cytokines. Immunity 2005, 23, 479-490. [CrossRef]

31. Baekkevold, E.S.; Roussigne, M.; Yamanaka, T.; Johansen, F.E.; Jahnsen, F.L.; Amalric, F.; Brandtzaeg, P.; Erard, M.; Haraldsen, G.; Girard, J.P. Molecular characterization of NF-HEV, a nuclear factor preferentially expressed in human high endothelial venules. Am. J. Pathol. 2003, 163, 69-79. [CrossRef]

32. Moussion, C.; Ortega, N.; Girard, J.P. The IL-1-like cytokine IL-33 is constitutively expressed in the nucleus of endothelial cells and epithelial cells in vivo: A novel 'alarmin'? PLoS ONE 2008, 3, e3331. [CrossRef] [PubMed]

33. Hardman, C.S.; Panova, V.; McKenzie, A.N. IL-33 citrine reporter mice reveal the temporal and spatial expression of IL-33 during allergic lung inflammation. Eur. J. Immunol. 2013, 43, 488-498. [CrossRef] [PubMed]

34. Pichery, M.; Mirey, E.; Mercier, P.; Lefrancais, E.; Dujardin, A.; Ortega, N.; Girard, J.P. Endogenous IL-33 is highly expressed in mouse epithelial barrier tissues, lymphoid organs, brain, embryos, and inflamed tissues: In situ analysis using a novel Il-33-LacZ gene trap reporter strain. J. Immunol. 2012, 188, 3488-3495. [CrossRef] [PubMed]

35. Paliard, X.; de Waal Malefijt, R.; Yssel, H.; Blanchard, D.; Chretien, I.; Abrams, J.; de Vries, J.; Spits, H. Simultaneous production of IL-2, IL-4, and IFN-gamma by activated human CD4+ and CD8+ T cell clones. J. Immunol. 1988, 141, 849-855. [PubMed]

36. Granucci, F.; Feau, S.; Angeli, V.; Trottein, F.; Ricciardi-Castagnoli, P. Early IL-2 production by mouse dendritic cells is the result of microbial-induced priming. J. Immunol. 2003, 170, 5075-5081. [CrossRef]

37. Potzl, J.; Roser, D.; Bankel, L.; Homberg, N.; Geishauser, A.; Brenner, C.D.; Weigand, M.; Rocken, M.; Mocikat, R. Reversal of tumor acidosis by systemic buffering reactivates NK cells to express IFN-gamma and induces NK cell-dependent lymphoma control without other immunotherapies. Int. J. Cancer 2017, 140, 2125-2133. [CrossRef]

38. Huffaker, T.B.; Hu, R.; Runtsch, M.C.; Bake, E.; Chen, X.; Zhao, J.; Round, J.L.; Baltimore, D.; O'Connell, R.M. Epistasis between microRNAs 155 and 146a during T cell-mediated antitumor immunity. Cell Rep. 2012, 2, 1697-1709. [CrossRef]

39. Klose, C.S.; Kiss, E.A.; Schwierzeck, V.; Ebert, K.; Hoyler, T.; d'Hargues, Y.; Goppert, N.; Croxford, A.L.; Waisman, A.; Tanriver, Y.; et al. A T-bet gradient controls the fate and function of CCR6-RORgammat+ innate lymphoid cells. Nature 2013, 494, 261-265. [CrossRef]

40. Rankin, L.C.; Groom, J.R.; Chopin, M.; Herold, M.J.; Walker, J.A.; Mielke, L.A.; McKenzie, A.N.; Carotta, S.; Nutt, S.L.; Belz, G.T. The transcription factor T-bet is essential for the development of NKp46+ innate lymphocytes via the Notch pathway. Nat. Immunol. 2013, 14, 389-395. [CrossRef]

41. Darwich, L.; Coma, G.; Pena, R.; Bellido, R.; Blanco, E.J.; Este, J.A.; Borras, F.E.; Clotet, B.; Ruiz, L.; Rosell, A.; et al. Secretion of interferon-gamma by human macrophages demonstrated at the single-cell level after costimulation with interleukin (IL)-12 plus IL-18. Immunology 2009, 126, 386-393. [CrossRef]

42. Molle, C.; Nguyen, M.; Flamand, V.; Renneson, J.; Trottein, F.; De Wit, D.; Willems, F.; Goldman, M.; Goriely, S. IL-27 synthesis induced by TLR ligation critically depends on IFN regulatory factor 3. J. Immunol. 2007, 178, 7607-7615. [CrossRef]

43. Pennock, N.D.; Gapin, L.; Kedl, R.M. IL-27 is required for shaping the magnitude, affinity distribution, and memory of T cells responding to subunit immunization. Proc. Natl. Acad. Sci. USA 2014, 111, 16472-16477. [CrossRef]

44. Kobayashi, M.; Fitz, L.; Ryan, M.; Hewick, R.M.; Clark, S.C.; Chan, S.; Loudon, R.; Sherman, F.; Perussia, B.; Trinchieri, G. Identification and purification of natural killer cell stimulatory factor (NKSF), a cytokine with multiple biologic effects on human lymphocytes. J. Exp. Med. 1989, 170, 827-845. [CrossRef]

45. Trinchieri, G.; Rengaraju, M.; D’Andrea, A.; Valiante, N.M.; Kubin, M.; Aste, M.; Chehimi, J. Producer cells of interleukin 12. Parasitol. Today 1993, 9, 97. [CrossRef] 
46. Fantini, M.C.; Becker, C.; Monteleone, G.; Pallone, F.; Galle, P.R.; Neurath, M.F. Cutting edge: TGF-beta induces a regulatory phenotype in CD4+CD25- T cells through Foxp3 induction and down-regulation of Smad7. J. Immunol. 2004, 172, 5149-5153. [CrossRef]

47. Schlenner, S.M.; Weigmann, B.; Ruan, Q.; Chen, Y.; von Boehmer, H. Smad3 binding to the foxp3 enhancer is dispensable for the development of regulatory T cells with the exception of the gut. J. Exp. Med. 2012, 209, 1529-1535. [CrossRef]

48. Boussiotis, V.A.; Chen, Z.M.; Zeller, J.C.; Murphy, W.J.; Berezovskaya, A.; Narula, S.; Roncarolo, M.G.; Blazar, B.R. Altered T-cell receptor + CD28-mediated signaling and blocked cell cycle progression in interleukin 10 and transforming growth factor-beta-treated alloreactive T cells that do not induce graft-versus-host disease. Blood 2001, 97, 565-571. [CrossRef]

49. Chen, C.H.; Seguin-Devaux, C.; Burke, N.A.; Oriss, T.B.; Watkins, S.C.; Clipstone, N.; Ray, A. Transforming growth factor beta blocks Tec kinase phosphorylation, Ca2+ influx, and NFATc translocation causing inhibition of T cell differentiation. J. Exp. Med. 2003, 197, 1689-1699. [CrossRef]

50. Gorelik, L.; Constant, S.; Flavell, R.A. Mechanism of transforming growth factor beta-induced inhibition of T helper type 1 differentiation. J. Exp. Med. 2002, 195, 1499-1505. [CrossRef]

51. Gorelik, L.; Fields, P.E.; Flavell, R.A. Cutting edge: TGF-beta inhibits Th type 2 development through inhibition of GATA-3 expression. J. Immunol. 2000, 165, 4773-4777. [CrossRef] [PubMed]

52. Takimoto, T.; Wakabayashi, Y.; Sekiya, T.; Inoue, N.; Morita, R.; Ichiyama, K.; Takahashi, R.; Asakawa, M.; Muto, G.; Mori, T.; et al. Smad2 and Smad3 are redundantly essential for the TGF-beta-mediated regulation of regulatory T plasticity and Th1 development. J. Immunol. 2010, 185, 842-855. [CrossRef] [PubMed]

53. Kuwahara, M.; Yamashita, M.; Shinoda, K.; Tofukuji, S.; Onodera, A.; Shinnakasu, R.; Motohashi, S.; Hosokawa, H.; Tumes, D.; Iwamura, C.; et al. The transcription factor Sox 4 is a downstream target of signaling by the cytokine TGF-beta and suppresses $\mathrm{T}(\mathrm{H}) 2$ differentiation. Nat. Immunol. 2012, 13, 778-786. [CrossRef] [PubMed]

54. Li, S.; Liu, M.; Do, M.H.; Chou, C.; Stamatiades, E.G.; Nixon, B.G.; Shi, W.; Zhang, X.; Li, P.; Gao, S.; et al. Cancer immunotherapy via targeted TGF-beta signalling blockade in TH cells. Nature 2020, 587, 121-125. [CrossRef] [PubMed]

55. Asadzadeh, Z.; Mohammadi, H.; Safarzadeh, E.; Hemmatzadeh, M.; Mahdian-Shakib, A.; Jadidi-Niaragh, F.; Azizi, G.; Baradaran, B. The paradox of Th17 cell functions in tumor immunity. Cell Immunol. 2017, 322, 15-25. [CrossRef] [PubMed]

56. Chalmin, F.; Mignot, G.; Bruchard, M.; Chevriaux, A.; Vegran, F.; Hichami, A.; Ladoire, S.; Derangere, V.; Vincent, J.; Masson, D.; et al. Stat3 and Gfi-1 transcription factors control Th17 cell immunosuppressive activity via the regulation of ectonucleotidase expression. Immunity 2012, 36, 362-373. [CrossRef]

57. Korn, T.; Mitsdoerffer, M.; Croxford, A.L.; Awasthi, A.; Dardalhon, V.A.; Galileos, G.; Vollmar, P.; Stritesky, G.L.; Kaplan, M.H.; Waisman, A.; et al. IL-6 controls Th17 immunity in vivo by inhibiting the conversion of conventional T cells into Foxp3+ regulatory T cells. Proc. Natl. Acad. Sci. USA 2008, 105, 18460-18465. [CrossRef]

58. Sharma, M.D.; Huang, L.; Choi, J.H.; Lee, E.J.; Wilson, J.M.; Lemos, H.; Pan, F.; Blazar, B.R.; Pardoll, D.M.; Mellor, A.L.; et al. An inherently bifunctional subset of Foxp3+ T helper cells is controlled by the transcription factor eos. Immunity 2013, 38, 998-1012. [CrossRef]

59. Yao, Z.; Kanno, Y.; Kerenyi, M.; Stephens, G.; Durant, L.; Watford, W.T.; Laurence, A.; Robinson, G.W.; Shevach, E.M.; Moriggl, R.; et al. Nonredundant roles for Stat5a/b in directly regulating Foxp3. Blood 2007, 109, 4368-4375. [CrossRef]

60. Kanai, T.; Seki, S.; Jenks, J.A.; Kohli, A.; Kawli, T.; Martin, D.P.; Snyder, M.; Bacchetta, R.; Nadeau, K.C. Identification of STAT5A and STAT5B target genes in human T cells. PLoS ONE 2014, 9, e86790. [CrossRef]

61. Liao, W.; Lin, J.X.; Wang, L.; Li, P.; Leonard, W.J. Modulation of cytokine receptors by IL-2 broadly regulates differentiation into helper T cell lineages. Nat. Immunol. 2011, 12, 551-559. [CrossRef] [PubMed]

62. Rani, A.; Afzali, B.; Kelly, A.; Tewolde-Berhan, L.; Hackett, M.; Kanhere, A.S.; Pedroza-Pacheco, I.; Bowen, H.; Jurcevic, S.; Jenner, R.G.; et al. IL-2 regulates expression of C-MAF in human CD4 T cells. J. Immunol. 2011, 187, 3721-3729. [CrossRef] [PubMed]

63. Liao, W.; Schones, D.E.; Oh, J.; Cui, Y.; Cui, K.; Roh, T.Y.; Zhao, K.; Leonard, W.J. Priming for T helper type 2 differentiation by interleukin 2-mediated induction of interleukin 4 receptor alpha-chain expression. Nat. Immunol. 2008, 9, 1288-1296. [CrossRef] [PubMed]

64. Yang, X.P.; Ghoreschi, K.; Steward-Tharp, S.M.; Rodriguez-Canales, J.; Zhu, J.; Grainger, J.R.; Hirahara, K.; Sun, H.W.; Wei, L.; Vahedi, G.; et al. Opposing regulation of the locus encoding IL-17 through direct, reciprocal actions of STAT3 and STAT5. Nat. Immunol. 2011, 12, 247-254. [CrossRef] [PubMed]

65. Oestreich, K.J.; Mohn, S.E.; Weinmann, A.S. Molecular mechanisms that control the expression and activity of Bcl-6 in TH1 cells to regulate flexibility with a TFH-like gene profile. Nat. Immunol. 2012, 13, 405-411. [CrossRef]

66. Bruni, D.; Angell, H.K.; Galon, J. The immune contexture and Immunoscore in cancer prognosis and therapeutic efficacy. Nat. Rev. Cancer 2020, 20, 662-680. [CrossRef] [PubMed]

67. Waldmann, T.A. Cytokines in Cancer Immunotherapy. Cold Spring Harb. Perspect. Biol. 2018, 10, a028472. [CrossRef] [PubMed]

68. Taniguchi, S.; Elhance, A.; Van Duzer, A.; Kumar, S.; Leitenberger, J.J.; Oshimori, N. Tumor-initiating cells establish an IL-33-TGFbeta niche signaling loop to promote cancer progression. Science 2020, 369. [CrossRef]

69. Bruchard, M.; Mignot, G.; Derangere, V.; Chalmin, F.; Chevriaux, A.; Vegran, F.; Boireau, W.; Simon, B.; Ryffel, B.; Connat, J.L.; et al. Chemotherapy-triggered cathepsin B release in myeloid-derived suppressor cells activates the Nlrp3 inflammasome and promotes tumor growth. Nat. Med. 2013, 19, 57-64. [CrossRef]

70. Vitiello, G.A.; Miller, G. Targeting the interleukin-17 immune axis for cancer immunotherapy. J. Exp. Med. 2020, 217. [CrossRef] 
71. Zhao, J.; Chen, X.; Herjan, T.; Li, X. The role of interleukin-17 in tumor development and progression. J. Exp. Med. 2020, 217, e20190297. [CrossRef] [PubMed]

72. Haabeth, O.A.; Lorvik, K.B.; Hammarstrom, C.; Donaldson, I.M.; Haraldsen, G.; Bogen, B.; Corthay, A. Inflammation driven by tumour-specific Th1 cells protects against B-cell cancer. Nat. Commun. 2011, 2, 240. [CrossRef]

73. Haabeth, O.A.; Lorvik, K.B.; Yagita, H.; Bogen, B.; Corthay, A. Interleukin-1 is required for cancer eradication mediated by tumor-specific Th1 cells. Oncoimmunology 2016, 5, e1039763. [CrossRef]

74. Végran, F.; Berger, H.; Boidot, R.; Mignot, G.; Bruchard, M.; Dosset, M.; Chalmin, F.; Rébé, C.; Dérangère, V.; Ryffel, B.; et al. The transcription factor IRF1 dictates the IL-21-dependent anticancer functions of TH9 cells. Nat. Immunol. 2014, 15, 758-766. [CrossRef]

75. Carswell, E.A.; Old, L.J.; Kassel, R.L.; Green, S.; Fiore, N.; Williamson, B. An endotoxin-induced serum factor that causes necrosis of tumors. Proc. Natl. Acad. Sci. USA 1975, 72, 3666-3670. [CrossRef]

76. Kearney, C.J.; Vervoort, S.J.; Hogg, S.J.; Ramsbottom, K.M.; Freeman, A.J.; Lalaoui, N.; Pijpers, L.; Michie, J.; Brown, K.K.; Knight, D.A.; et al. Tumor immune evasion arises through loss of TNF sensitivity. Sci. Immunol. 2018, 3. [CrossRef]

77. Chen, X.; Baumel, M.; Mannel, D.N.; Howard, O.M.; Oppenheim, J.J. Interaction of TNF with TNF receptor type 2 promotes expansion and function of mouse CD4+CD25+ T regulatory cells. J. Immunol. 2007, 179, 154-161. [CrossRef]

78. Chen, X.; Wu, X.; Zhou, Q.; Howard, O.M.; Netea, M.G.; Oppenheim, J.J. TNFR2 is critical for the stabilization of the CD4+Foxp3+ regulatory T. cell phenotype in the inflammatory environment. J. Immunol. 2013, 190, 1076-1084. [CrossRef]

79. Wang, D.; Shao, Y.; Zhang, X.; Lu, G.; Liu, B. IL-23 and PSMA-targeted duo-CAR T cells in Prostate Cancer Eradication in a preclinical model. J. Transl. Med. 2020, 18, 23. [CrossRef]

80. Berger, H.; Vegran, F.; Chikh, M.; Gilardi, F.; Ladoire, S.; Bugaut, H.; Mignot, G.; Chalmin, F.; Bruchard, M.; Derangere, V.; et al. SOCS3 transactivation by PPARgamma prevents IL-17-driven cancer growth. Cancer Res. 2013, 73, 3578-3590. [CrossRef]

81. Liu, M.; Kuo, F.; Capistrano, K.J.; Kang, D.; Nixon, B.G.; Shi, W.; Chou, C.; Do, M.H.; Stamatiades, E.G.; Gao, S.; et al. TGF-beta suppresses type 2 immunity to cancer. Nature 2020, 587, 115-120. [CrossRef] [PubMed]

82. Zelba, H.; Weide, B.; Martens, A.; Derhovanessian, E.; Bailur, J.K.; Kyzirakos, C.; Pflugfelder, A.; Eigentler, T.K.; Di Giacomo, A.M.; Maio, M.; et al. Circulating CD4+ T cells that produce IL4 or IL17 when stimulated by melan-A but not by NY-ESO-1 have negative impacts on survival of patients with stage IV melanoma. Clin. Cancer Res. Off. J. Am. Assoc. Cancer Res. 2014, 20, 4390-4399. [CrossRef] [PubMed]

83. Gabitass, R.F.; Annels, N.E.; Stocken, D.D.; Pandha, H.A.; Middleton, G.W. Elevated myeloid-derived suppressor cells in pancreatic, esophageal and gastric cancer are an independent prognostic factor and are associated with significant elevation of the Th2 cytokine interleukin-13. Cancer Immunol. Immunother. 2011, 60, 1419-1430. [CrossRef] [PubMed]

84. Hatzioannou, A.; Banos, A.; Sakelaropoulos, T.; Fedonidis, C.; Vidali, M.S.; Kohne, M.; Handler, K.; Boon, L.; Henriques, A.; Koliaraki, V.; et al. An intrinsic role of IL-33 in Treg cell-mediated tumor immunoevasion. Nat. Immunol. 2020, $21,75-85$. [CrossRef] [PubMed]

85. Schiering, C.; Krausgruber, T.; Chomka, A.; Frohlich, A.; Adelmann, K.; Wohlfert, E.A.; Pott, J.; Griseri, T.; Bollrath, J.; Hegazy, A.N.; et al. The alarmin IL-33 promotes regulatory T-cell function in the intestine. Nature 2014, 513, 564-568. [CrossRef] [PubMed]

86. Zitvogel, L.; Galluzzi, L.; Kepp, O.; Smyth, M.J.; Kroemer, G. Type I interferons in anticancer immunity. Nat. Rev. Immunol. 2015, 15, 405-414. [CrossRef]

87. Kurche, J.S.; Haluszczak, C.; McWilliams, J.A.; Sanchez, P.J.; Kedl, R.M. Type I IFN-dependent T cell activation is mediated by IFN-dependent dendritic cell OX40 ligand expression and is independent of T cell IFNR expression. J. Immunol. 2012, 188, 585-593. [CrossRef]

88. Hashimoto, H.; Ueda, R.; Narumi, K.; Heike, Y.; Yoshida, T.; Aoki, K. Type I IFN gene delivery suppresses regulatory T cells within tumors. Cancer Gene 2014, 21, 532-541. [CrossRef]

89. Zaidi, M.R. The Interferon-Gamma Paradox in Cancer. J. Interferon Cytokine Res. Off. J. Int. Soc. Interferon Cytokine Res. 2019, 39, 30-38. [CrossRef]

90. Lasfar, A.; Gogas, H.; Zloza, A.; Kaufman, H.L.; Kirkwood, J.M. IFN-lambda cancer immunotherapy: New kid on the block. Immunotherapy 2016, 8, 877-888. [CrossRef]

91. Abushahba, W.; Balan, M.; Castaneda, I.; Yuan, Y.; Reuhl, K.; Raveche, E.; de la Torre, A.; Lasfar, A.; Kotenko, S.V. Antitumor activity of type I and type III interferons in BNL hepatoma model. Cancer Immunol. Immunother. 2010, 59, 1059-1071. [CrossRef] [PubMed]

92. Sato, A.; Ohtsuki, M.; Hata, M.; Kobayashi, E.; Murakami, T. Antitumor activity of IFN-lambda in murine tumor models. J. Immunol. 2006, 176, 7686-7694. [CrossRef] [PubMed]

93. Tezuka, Y.; Endo, S.; Matsui, A.; Sato, A.; Saito, K.; Semba, K.; Takahashi, M.; Murakami, T. Potential anti-tumor effect of IFN-lambda2 (IL-28A) against human lung cancer cells. Lung Cancer 2012, 78, 185-192. [CrossRef] [PubMed]

94. Zhu, J.; Paul, W.E. Heterogeneity and plasticity of T helper cells. Cell Res. 2010, 20, 4-12. [CrossRef]

95. Tugues, S.; Burkhard, S.H.; Ohs, I.; Vrohlings, M.; Nussbaum, K.; Vom Berg, J.; Kulig, P.; Becher, B. New insights into IL-12mediated tumor suppression. Cell Death Differ. 2015, 22, 237-246. [CrossRef]

96. Tait Wojno, E.D.; Hunter, C.A.; Stumhofer, J.S. The Immunobiology of the Interleukin-12 Family: Room for Discovery. Immunity 2019, 50, 851-870. [CrossRef] 
97. Choi, Y.S.; Eto, D.; Yang, J.A.; Lao, C.; Crotty, S. Cutting edge: STAT1 is required for IL-6-mediated Bcl6 induction for early follicular helper cell differentiation. J. Immunol. 2013, 190, 3049-3053. [CrossRef]

98. Johnson, D.E.; O'Keefe, R.A.; Grandis, J.R. Targeting the IL-6/JAK/STAT3 signalling axis in cancer. Nat. Rev. Clin. Oncol. 2018, 15, 234-248. [CrossRef]

99. Hunter, C.A.; Jones, S.A. IL-6 as a keystone cytokine in health and disease. Nat. Immunol. 2015, 16, 448-457. [CrossRef]

100. Atsumi, T.; Singh, R.; Sabharwal, L.; Bando, H.; Meng, J.; Arima, Y.; Yamada, M.; Harada, M.; Jiang, J.J.; Kamimura, D.; et al. Inflammation amplifier, a new paradigm in cancer biology. Cancer Res. 2014, 74, 8-14. [CrossRef]

101. Yang, H.Y.; Barbi, J.; Wu, C.Y.; Zheng, Y.; Vignali, P.D.; Wu, X.; Tao, J.H.; Park, B.V.; Bandara, S.; Novack, L.; et al. MicroRNA-17 Modulates Regulatory T Cell Function by Targeting Co-regulators of the Foxp3 Transcription Factor. Immunity 2016, 45, 83-93. [CrossRef] [PubMed]

102. Malek, T.R. The biology of interleukin-2. Annu. Rev. Immunol. 2008, 26, 453-479. [CrossRef] [PubMed]

103. Rosenberg, S.A. IL-2: The first effective immunotherapy for human cancer. J. Immunol. 2014, 192, 5451-5458. [CrossRef] [PubMed]

104. Finlay, D.K.; Rosenzweig, E.; Sinclair, L.V.; Feijoo-Carnero, C.; Hukelmann, J.L.; Rolf, J.; Panteleyev, A.A.; Okkenhaug, K.; Cantrell, D.A. PDK1 regulation of $\mathrm{mTOR}$ and hypoxia-inducible factor 1 integrate metabolism and migration of CD8+ T cells. J. Exp. Med. 2012, 209, 2441-2453. [CrossRef] [PubMed]

105. Beadling, C.; Guschin, D.; Witthuhn, B.A.; Ziemiecki, A.; Ihle, J.N.; Kerr, I.M.; Cantrell, D.A. Activation of JAK kinases and STAT proteins by interleukin-2 and interferon alpha, but not the T cell antigen receptor, in human T lymphocytes. EMBO J. 1994, 13, 5605-5615. [CrossRef]

106. Johnston, J.A.; Bacon, C.M.; Finbloom, D.S.; Rees, R.C.; Kaplan, D.; Shibuya, K.; Ortaldo, J.R.; Gupta, S.; Chen, Y.Q.; Giri, J.D.; et al. Tyrosine phosphorylation and activation of STAT5, STAT3, and Janus kinases by interleukins 2 and 15. Proc. Natl. Acad. Sci. USA 1995, 92, 8705-8709. [CrossRef]

107. Beadling, C.; Ng, J.; Babbage, J.W.; Cantrell, D.A. Interleukin-2 activation of STAT5 requires the convergent action of tyrosine kinases and a serine/threonine kinase pathway distinct from the Raf1/ERK2 MAP kinase pathway. EMBO J. 1996, 15, $1902-1913$. [CrossRef]

108. Villarino, A.; Laurence, A.; Robinson, G.W.; Bonelli, M.; Dema, B.; Afzali, B.; Shih, H.Y.; Sun, H.W.; Brooks, S.R.; Hennighausen, L.; et al. Signal transducer and activator of transcription 5 (STAT5) paralog dose governs $\mathrm{T}$ cell effector and regulatory functions. Elife 2016, 5, e08384. [CrossRef]

109. Rickert, M.; Wang, X.; Boulanger, M.J.; Goriatcheva, N.; Garcia, K.C. The structure of interleukin-2 complexed with its alpha receptor. Science 2005, 308, 1477-1480. [CrossRef]

110. Banchereau, J.; Pascual, V.; O'Garra, A. From IL-2 to IL-37: The expanding spectrum of anti-inflammatory cytokines. Nat. Immunol. 2012, 13, 925-931. [CrossRef]

111. Lu, Y.; Wang, Q.; Xue, G.; Bi, E.; Ma, X.; Wang, A.; Qian, J.; Dong, C.; Yi, Q. Th9 Cells Represent a Unique Subset of CD4(+) T Cells Endowed with the Ability to Eradicate Advanced Tumors. Cancer Cell 2018, 33, 1048-1060.e1047. [CrossRef] [PubMed]

112. Xue, G.; Jin, G.; Fang, J.; Lu, Y. IL-4 together with IL-1beta induces antitumor Th9 cell differentiation in the absence of TGF-beta signaling. Nat. Commun. 2019, 10, 1376. [CrossRef] [PubMed]

113. Veltri, S.; Smith, J.W., 2nd. Interleukin 1 trials in cancer patients: A review of the toxicity, antitumor and hematopoietic effects. Stem Cells 1996, 14, 164-176. [CrossRef]

114. Mortara, L.; Balza, E.; Sassi, F.; Castellani, P.; Carnemolla, B.; De Lerma Barbaro, A.; Fossati, S.; Tosi, G.; Accolla, R.S.; Borsi, L. Therapy-induced antitumor vaccination by targeting tumor necrosis factor alpha to tumor vessels in combination with melphalan. Eur. J. Immunol. 2007, 37, 3381-3392. [CrossRef] [PubMed]

115. Habtetsion, T.; Ding, Z.C.; Pi, W.; Li, T.; Lu, C.; Chen, T.; Xi, C.; Spartz, H.; Liu, K.; Hao, Z.; et al. Alteration of Tumor Metabolism by CD4+ T Cells Leads to TNF-alpha-Dependent Intensification of Oxidative Stress and Tumor Cell Death. Cell Metab. 2018, 28, 228-242.e226. [CrossRef] [PubMed]

116. Moore, R.J.; Owens, D.M.; Stamp, G.; Arnott, C.; Burke, F.; East, N.; Holdsworth, H.; Turner, L.; Rollins, B.; Pasparakis, M.; et al. Mice deficient in tumor necrosis factor-alpha are resistant to skin carcinogenesis. Nat. Med. 1999, 5, 828-831. [CrossRef] [PubMed]

117. Candido, J.; Hagemann, T. Cancer-related inflammation. J. Clin. Immunol. 2013, 33 (Suppl. 1), S79-S84. [CrossRef]

118. Hamano, R.; Huang, J.; Yoshimura, T.; Oppenheim, J.J.; Chen, X. TNF optimally activatives regulatory T cells by inducing TNF receptor superfamily members TNFR2, 4-1BB and OX40. Eur. J. Immunol. 2011, 41, 2010-2020. [CrossRef]

119. Chen, X.; Subleski, J.J.; Hamano, R.; Howard, O.M.; Wiltrout, R.H.; Oppenheim, J.J. Co-expression of TNFR2 and CD25 identifies more of the functional CD4+FOXP3+ regulatory T cells in human peripheral blood. Eur. J. Immunol. 2010, 40, 1099-1106. [CrossRef]

120. van Mierlo, G.J.; Scherer, H.U.; Hameetman, M.; Morgan, M.E.; Flierman, R.; Huizinga, T.W.; Toes, R.E. Cutting edge: TNFRshedding by CD4+CD25+ regulatory T cells inhibits the induction of inflammatory mediators. J. Immunol. 2008, 180, $2747-2751$. [CrossRef]

121. Charles, K.A.; Kulbe, H.; Soper, R.; Escorcio-Correia, M.; Lawrence, T.; Schultheis, A.; Chakravarty, P.; Thompson, R.G.; Kollias, G.; Smyth, J.F.; et al. The tumor-promoting actions of TNF-alpha involve TNFR1 and IL-17 in ovarian cancer in mice and humans. J. Clin. Investig. 2009, 119, 3011-3023. [CrossRef] [PubMed] 
122. Torrey, H.; Butterworth, J.; Mera, T.; Okubo, Y.; Wang, L.; Baum, D.; Defusco, A.; Plager, S.; Warden, S.; Huang, D.; et al. Targeting TNFR2 with antagonistic antibodies inhibits proliferation of ovarian cancer cells and tumor-associated Tregs. Sci. Signal 2017, 10. [CrossRef] [PubMed]

123. Donia, M.; Andersen, R.; Kjeldsen, J.W.; Fagone, P.; Munir, S.; Nicoletti, F.; Andersen, M.H.; Thor Straten, P.; Svane, I.M. Aberrant Expression of MHC Class II in Melanoma Attracts Inflammatory Tumor-Specific CD4+ T- Cells, Which Dampen CD8+ T-cell Antitumor Reactivity. Cancer Res. 2015, 75, 3747-3759. [CrossRef] [PubMed]

124. Grivennikov, S.I.; Wang, K.; Mucida, D.; Stewart, C.A.; Schnabl, B.; Jauch, D.; Taniguchi, K.; Yu, G.Y.; Osterreicher, C.H.; Hung, K.E.; et al. Adenoma-linked barrier defects and microbial products drive IL-23/IL-17-mediated tumour growth. Nature 2012, 491, 254-258. [CrossRef] [PubMed]

125. Teng, M.W.; Bowman, E.P.; McElwee, J.J.; Smyth, M.J.; Casanova, J.L.; Cooper, A.M.; Cua, D.J. IL-12 and IL-23 cytokines: From discovery to targeted therapies for immune-mediated inflammatory diseases. Nat. Med. 2015, 21, 719-729. [CrossRef]

126. Coussens, L.M.; Zitvogel, L.; Palucka, A.K. Neutralizing tumor-promoting chronic inflammation: A magic bullet? Science 2013, 339, 286-291. [CrossRef]

127. Wang, W.; Zou, W. Amino Acids and Their Transporters in T Cell Immunity and Cancer Therapy. Mol. Cell 2020, 80, 384-395. [CrossRef]

128. Sivick, K.E.; Desbien, A.L.; Glickman, L.H.; Reiner, G.L.; Corrales, L.; Surh, N.H.; Hudson, T.E.; Vu, U.T.; Francica, B.J.; Banda, T.; et al. Magnitude of Therapeutic STING Activation Determines CD8(+) T Cell-Mediated Anti-tumor Immunity. Cell Rep. 2018, 25, 3074-3085.e3075. [CrossRef]

129. Lu, C.; Klement, J.D.; Ibrahim, M.L.; Xiao, W.; Redd, P.S.; Nayak-Kapoor, A.; Zhou, G.; Liu, K. Type I interferon suppresses tumor growth through activating the STAT3-granzyme B pathway in tumor-infiltrating cytotoxic T lymphocytes. J. Immunother. Cancer 2019, 7, 157. [CrossRef]

130. Chen, J.; Cao, Y.; Markelc, B.; Kaeppler, J.; Vermeer, J.A.; Muschel, R.J. Type I IFN protects cancer cells from CD8+ T cell-mediated cytotoxicity after radiation. J. Clin. Investig. 2019, 129, 4224-4238. [CrossRef]

131. Evgin, L.; Huff, A.L.; Wongthida, P.; Thompson, J.; Kottke, T.; Tonne, J.; Schuelke, M.; Ayasoufi, K.; Driscoll, C.B.; Shim, K.G.; et al. Oncolytic virus-derived type I interferon restricts CAR T cell therapy. Nat. Commun. 2020, 11, 3187. [CrossRef] [PubMed]

132. Zhang, S.; Kodys, K.; Li, K.; Szabo, G. Human type 2 myeloid dendritic cells produce interferon-lambda and amplify interferonalpha in response to hepatitis C virus infection. Gastroenterology 2013, 144, 414-425.e417. [CrossRef] [PubMed]

133. Zanoni, I.; Granucci, F.; Broggi, A. Interferon (IFN)-lambda Takes the Helm: Immunomodulatory Roles of Type III IFNs. Front. Immunol. 2017, 8, 1661. [CrossRef] [PubMed]

134. Zhang, H.; Chua, K.S.; Guimond, M.; Kapoor, V.; Brown, M.V.; Fleisher, T.A.; Long, L.M.; Bernstein, D.; Hill, B.J.; Douek, D.C.; et al. Lymphopenia and interleukin-2 therapy alter homeostasis of CD4+CD25+ regulatory T cells. Nat. Med. 2005, 11, 1238-1243. [CrossRef]

135. Bentebibel, S.E.; Hurwitz, M.E.; Bernatchez, C.; Haymaker, C.; Hudgens, C.W.; Kluger, H.M.; Tetzlaff, M.T.; Tagliaferri, M.A.; Zalevsky, J.; Hoch, U.; et al. A First-in-Human Study and Biomarker Analysis of NKTR-214, a Novel IL2Rbetagamma-Biased Cytokine, in Patients with Advanced or Metastatic Solid Tumors. Cancer Discov. 2019, 9, 711-721. [CrossRef]

136. Diab, A.; Tannir, N.M.; Bentebibel, S.E.; Hwu, P.; Papadimitrakopoulou, V.; Haymaker, C.; Kluger, H.M.; Gettinger, S.N.; Sznol, M.; Tykodi, S.S.; et al. Bempegaldesleukin (NKTR-214) plus Nivolumab in Patients with Advanced Solid Tumors: Phase I Dose-Escalation Study of Safety, Efficacy, and Immune Activation (PIVOT-02). Cancer Discov. 2020, 10, 1158-1173. [CrossRef]

137. Charych, D.H.; Hoch, U.; Langowski, J.L.; Lee, S.R.; Addepalli, M.K.; Kirk, P.B.; Sheng, D.; Liu, X.; Sims, P.W.; VanderVeen, L.A.; et al. NKTR-214, an Engineered Cytokine with Biased IL2 Receptor Binding, Increased Tumor Exposure, and Marked Efficacy in Mouse Tumor Models. Clin. Cancer Res. Off. J. Am. Assoc. Cancer Res. 2016, 22, 680-690. [CrossRef]

138. Heaton, K.M.; Ju, G.; Grimm, E.A. Human interleukin 2 analogues that preferentially bind the intermediate-affinity interleukin 2 receptor lead to reduced secondary cytokine secretion: Implications for the use of these interleukin 2 analogues in cancer immunotherapy. Cancer Res. 1993, 53, 2597-2602.

139. Sun, Z.; Ren, Z.; Yang, K.; Liu, Z.; Cao, S.; Deng, S.; Xu, L.; Liang, Y.; Guo, J.; Bian, Y.; et al. A next-generation tumor-targeting IL-2 preferentially promotes tumor-infiltrating CD8(+) T-cell response and effective tumor control. Nat. Commun. 2019, 10, 3874. [CrossRef]

140. Skak, K.; Frederiksen, K.S.; Lundsgaard, D. Interleukin-21 activates human natural killer cells and modulates their surface receptor expression. Immunology 2008, 123, 575-583. [CrossRef]

141. Jure-Kunkel, M.; Masters, G.; Girit, E.; Dito, G.; Lee, F.; Hunt, J.T.; Humphrey, R. Synergy between chemotherapeutic agents and CTLA-4 blockade in preclinical tumor models. Cancer Immunol. Immunother. 2013, 62, 1533-1545. [CrossRef] [PubMed]

142. Kowalczyk, A.; Wierzbicki, A.; Gil, M.; Bambach, B.; Kaneko, Y.; Rokita, H.; Repasky, E.; Fenstermaker, R.; Brecher, M.; Ciesielski, M.; et al. Induction of protective immune responses against NXS2 neuroblastoma challenge in mice by immunotherapy with GD2 mimotope vaccine and IL-15 and IL-21 gene delivery. Cancer Immunol. Immunother. 2007, 56, 1443-1458. [CrossRef] [PubMed]

143. Waugh, J.; Perry, C.M. Anakinra: A review of its use in the management of rheumatoid arthritis. BioDrugs 2005, 19, 189-202. [CrossRef] [PubMed]

144. Lust, J.A.; Lacy, M.Q.; Zeldenrust, S.R.; Dispenzieri, A.; Gertz, M.A.; Witzig, T.E.; Kumar, S.; Hayman, S.R.; Russell, S.J.; Buadi, F.K.; et al. Induction of a chronic disease state in patients with smoldering or indolent multiple myeloma by targeting interleukin 1\{beta\}-induced interleukin 6 production and the myeloma proliferative component. Mayo Clin. Proc. 2009, 84, 114-122. [CrossRef] 
145. Lust, J.A.; Lacy, M.Q.; Zeldenrust, S.R.; Witzig, T.E.; Moon-Tasson, L.L.; Dinarello, C.A.; Donovan, K.A. Reduction in C-reactive protein indicates successful targeting of the IL-1/IL-6 axis resulting in improved survival in early stage multiple myeloma. Am. J. Hematol. 2016, 91, 571-574. [CrossRef]

146. Isambert, N.; Hervieu, A.; Rebe, C.; Hennequin, A.; Borg, C.; Zanetta, S.; Chevriaux, A.; Richard, C.; Derangere, V.; Limagne, E.; et al. Fluorouracil and bevacizumab plus anakinra for patients with metastatic colorectal cancer refractory to standard therapies (IRAFU): A single-arm phase 2 study. Oncoimmunology 2018, 7, e1474319. [CrossRef]

147. Dubois, E.A.; Rissmann, R.; Cohen, A.F. Rilonacept and canakinumab. Br. J. Clin. Pharm. 2011, 71, 639-641. [CrossRef]

148. Fizazi, K.; De Bono, J.S.; Flechon, A.; Heidenreich, A.; Voog, E.; Davis, N.B.; Qi, M.; Bandekar, R.; Vermeulen, J.T.; Cornfeld, M.; et al. Randomised phase II study of siltuximab (CNTO 328), an anti-IL-6 monoclonal antibody, in combination with mitoxantrone/prednisone versus mitoxantrone/prednisone alone in metastatic castration-resistant prostate cancer. Eur. J. Cancer 2012, 48, 85-93. [CrossRef]

149. Rossi, J.F.; Negrier, S.; James, N.D.; Kocak, I.; Hawkins, R.; Davis, H.; Prabhakar, U.; Qin, X.; Mulders, P.; Berns, B. A phase I/II study of siltuximab (CNTO 328), an anti-interleukin-6 monoclonal antibody, in metastatic renal cell cancer. Br. J. Cancer 2010, 103, 1154-1162. [CrossRef]

150. Dijkgraaf, E.M.; Santegoets, S.J.; Reyners, A.K.; Goedemans, R.; Wouters, M.C.; Kenter, G.G.; van Erkel, A.R.; van Poelgeest, M.I.; Nijman, H.W.; van der Hoeven, J.J.; et al. A phase I trial combining carboplatin/doxorubicin with tocilizumab, an anti-IL-6R monoclonal antibody, and interferon-alpha2b in patients with recurrent epithelial ovarian cancer. Ann. Oncol. 2015, 26, 2141-2149. [CrossRef]

151. Ghiringhelli, F.; Larmonier, N.; Schmitt, E.; Parcellier, A.; Cathelin, D.; Garrido, C.; Chauffert, B.; Solary, E.; Bonnotte, B.; Martin, F. CD4+CD25+ regulatory $T$ cells suppress tumor immunity but are sensitive to cyclophosphamide which allows immunotherapy of established tumors to be curative. Eur. J. Immunol. 2004, 34, 336-344. [CrossRef]

152. Zhang, L.; Dermawan, K.; Jin, M.; Liu, R.; Zheng, H.; Xu, L.; Zhang, Y.; Cai, Y.; Chu, Y.; Xiong, S. Differential impairment of regulatory $\mathrm{T}$ cells rather than effector $\mathrm{T}$ cells by paclitaxel-based chemotherapy. Clin. Immunol. 2008, 129, 219-229. [CrossRef] [PubMed]

153. Ridolfi, L.; Petrini, M.; Granato, A.M.; Gentilcore, G.; Simeone, E.; Ascierto, P.A.; Pancisi, E.; Ancarani, V.; Fiammenghi, L.; Guidoboni, M.; et al. Low-dose temozolomide before dendritic-cell vaccination reduces (specifically) CD4+CD25++Foxp3+ regulatory T-cells in advanced melanoma patients. J. Transl. Med. 2013, 11, 135. [CrossRef] [PubMed]

154. Larmonier, N.; Janikashvili, N.; LaCasse, C.J.; Larmonier, C.B.; Cantrell, J.; Situ, E.; Lundeen, T.; Bonnotte, B.; Katsanis, E. Imatinib mesylate inhibits CD4+ CD25+ regulatory T cell activity and enhances active immunotherapy against BCR-ABL- tumors. $J$. Immunol. 2008, 181, 6955-6963. [CrossRef] [PubMed]

155. Zhao, J.; Cao, Y.; Lei, Z.; Yang, Z.; Zhang, B.; Huang, B. Selective depletion of CD4+CD25+Foxp3+ regulatory T cells by low-dose cyclophosphamide is explained by reduced intracellular ATP levels. Cancer Res. 2010, 70, 4850-4858. [CrossRef]

156. Viaud, S.; Flament, C.; Zoubir, M.; Pautier, P.; LeCesne, A.; Ribrag, V.; Soria, J.C.; Marty, V.; Vielh, P.; Robert, C.; et al. Cyclophosphamide induces differentiation of Th17 cells in cancer patients. Cancer Res. 2011, 71, 661-665. [CrossRef]

157. Balachandran, V.P.; Cavnar, M.J.; Zeng, S.; Bamboat, Z.M.; Ocuin, L.M.; Obaid, H.; Sorenson, E.C.; Popow, R.; Ariyan, C.; Rossi, F.; et al. Imatinib potentiates antitumor $\mathrm{T}$ cell responses in gastrointestinal stromal tumor through the inhibition of Ido. Nat. Med. 2011, 17, 1094-1100. [CrossRef]

158. Tanaka, A.; Nishikawa, H.; Noguchi, S.; Sugiyama, D.; Morikawa, H.; Takeuchi, Y.; Ha, D.; Shigeta, N.; Kitawaki, T.; Maeda, Y.; et al. Tyrosine kinase inhibitor imatinib augments tumor immunity by depleting effector regulatory T cells. J. Exp. Med. 2020, 217, e20191009. [CrossRef]

159. Vicari, A.P.; Luu, R.; Zhang, N.; Patel, S.; Makinen, S.R.; Hanson, D.C.; Weeratna, R.D.; Krieg, A.M. Paclitaxel reduces regulatory $\mathrm{T}$ cell numbers and inhibitory function and enhances the anti-tumor effects of the TLR9 agonist PF-3512676 in the mouse. Cancer Immunol. Immunother. 2009, 58, 615-628. [CrossRef]

160. Heeren, A.M.; van Luijk, I.F.; Lakeman, J.; Pocorni, N.; Kole, J.; de Menezes, R.X.; Kenter, G.G.; Bosse, T.; de Kroon, C.D.; Jordanova, E.S. Neoadjuvant cisplatin and paclitaxel modulate tumor-infiltrating T cells in patients with cervical cancer. Cancer Immunol. Immunother. 2019, 68, 1759-1767. [CrossRef]

161. Quirt, I.; Verma, S.; Petrella, T.; Bak, K.; Charette, M. Temozolomide for the treatment of metastatic melanoma: A systematic review. Oncologist 2007, 12, 1114-1123. [CrossRef] [PubMed]

162. Iversen, T.Z.; Brimnes, M.K.; Nikolajsen, K.; Andersen, R.S.; Hadrup, S.R.; Andersen, M.H.; Bastholt, L.; Svane, I.M. Depletion of $\mathrm{T}$ lymphocytes is correlated with response to temozolomide in melanoma patients. Oncoimmunology 2013, 2, e23288. [CrossRef] [PubMed]

163. Borghaei, H.; Paz-Ares, L.; Horn, L.; Spigel, D.R.; Steins, M.; Ready, N.E.; Chow, L.Q.; Vokes, E.E.; Felip, E.; Holgado, E.; et al. Nivolumab versus Docetaxel in Advanced Nonsquamous Non-Small-Cell Lung Cancer. N. Engl. J. Med. 2015, 373, 1627-1639. [CrossRef] [PubMed]

164. Garon, E.B.; Rizvi, N.A.; Hui, R.; Leighl, N.; Balmanoukian, A.S.; Eder, J.P.; Patnaik, A.; Aggarwal, C.; Gubens, M.; Horn, L.; et al. Pembrolizumab for the treatment of non-small-cell lung cancer. N. Engl. J. Med. 2015, 372, 2018-2028. [CrossRef]

165. Larkin, J.; Chiarion-Sileni, V.; Gonzalez, R.; Grob, J.J.; Cowey, C.L.; Lao, C.D.; Schadendorf, D.; Dummer, R.; Smylie, M.; Rutkowski, P.; et al. Combined Nivolumab and Ipilimumab or Monotherapy in Untreated Melanoma. N. Engl. J. Med. 2015, 373, 23-34. [CrossRef] 
166. Schadendorf, D.; Wolchok, J.D.; Hodi, F.S.; Chiarion-Sileni, V.; Gonzalez, R.; Rutkowski, P.; Grob, J.J.; Cowey, C.L.; Lao, C.D.; Chesney, J.; et al. Efficacy and Safety Outcomes in Patients With Advanced Melanoma Who Discontinued Treatment With Nivolumab and Ipilimumab Because of Adverse Events: A Pooled Analysis of Randomized Phase II and III Trials. J. Clin. Oncol. 2017, 35, 3807-3814. [CrossRef]

167. Powles, T.; Eder, J.P.; Fine, G.D.; Braiteh, F.S.; Loriot, Y.; Cruz, C.; Bellmunt, J.; Burris, H.A.; Petrylak, D.P.; Teng, S.L.; et al. MPDL3280A (anti-PD-L1) treatment leads to clinical activity in metastatic bladder cancer. Nature 2014, 515, 558-562. [CrossRef]

168. Rittmeyer, A.; Barlesi, F.; Waterkamp, D.; Park, K.; Ciardiello, F.; von Pawel, J.; Gadgeel, S.M.; Hida, T.; Kowalski, D.M.; Dols, M.C.; et al. Atezolizumab versus docetaxel in patients with previously treated non-small-cell lung cancer (OAK): A phase 3, open-label, multicentre randomised controlled trial. Lancet 2017, 389, 255-265. [CrossRef]

169. Horn, L.; Mansfield, A.S.; Szczesna, A.; Havel, L.; Krzakowski, M.; Hochmair, M.J.; Huemer, F.; Losonczy, G.; Johnson, M.L.; Nishio, M.; et al. First-Line Atezolizumab plus Chemotherapy in Extensive-Stage Small-Cell Lung Cancer. N. Engl. J. Med. 2018, 379, 2220-2229. [CrossRef]

170. McDermott, D.F.; Sosman, J.A.; Sznol, M.; Massard, C.; Gordon, M.S.; Hamid, O.; Powderly, J.D.; Infante, J.R.; Fasso, M.; Wang, Y.V.; et al. Atezolizumab, an Anti-Programmed Death-Ligand 1 Antibody, in Metastatic Renal Cell Carcinoma: Long-Term Safety, Clinical Activity, and Immune Correlates From a Phase Ia Study. J. Clin. Oncol. 2016, 34, 833-842. [CrossRef]

171. Schmid, P.; Adams, S.; Rugo, H.S.; Schneeweiss, A.; Barrios, C.H.; Iwata, H.; Dieras, V.; Hegg, R.; Im, S.A.; Shaw Wright, G.; et al. Atezolizumab and Nab-Paclitaxel in Advanced Triple-Negative Breast Cancer. N. Engl. J. Med. 2018, 379, 2108-2121. [CrossRef] [PubMed]

172. Polk, A.; Svane, I.M.; Andersson, M.; Nielsen, D. Checkpoint inhibitors in breast cancer-Current status. Cancer Treat. Rev. 2018, 63, 122-134. [CrossRef] [PubMed]

173. Ansell, S.M.; Lesokhin, A.M.; Borrello, I.; Halwani, A.; Scott, E.C.; Gutierrez, M.; Schuster, S.J.; Millenson, M.M.; Cattry, D.; Freeman, G.J.; et al. PD-1 blockade with nivolumab in relapsed or refractory Hodgkin's lymphoma. N. Engl. J. Med. 2015, 372, 311-319. [CrossRef] [PubMed]

174. Ferrara, R.; Imbimbo, M.; Malouf, R.; Paget-Bailly, S.; Calais, F.; Marchal, C.; Westeel, V. Single or combined immune checkpoint inhibitors compared to first-line platinum-based chemotherapy with or without bevacizumab for people with advanced non-small cell lung cancer. Cochrane Database Syst. Rev. 2020, 12, CD013257. [CrossRef]

175. Rotte, A.; Jin, J.Y.; Lemaire, V. Mechanistic overview of immune checkpoints to support the rational design of their combinations in cancer immunotherapy. Ann. Oncol. 2018, 29, 71-83. [CrossRef]

176. Chan, T.A.; Yarchoan, M.; Jaffee, E.; Swanton, C.; Quezada, S.A.; Stenzinger, A.; Peters, S. Development of tumor mutation burden as an immunotherapy biomarker: Utility for the oncology clinic. Ann. Oncol. 2019, 30, 44-56. [CrossRef]

177. Le, H.K.; Graham, L.; Cha, E.; Morales, J.K.; Manjili, M.H.; Bear, H.D. Gemcitabine directly inhibits myeloid derived suppressor cells in BALB/c mice bearing 4T1 mammary carcinoma and augments expansion of T cells from tumor-bearing mice. Int. Immunopharmacol. 2009, 9, 900-909. [CrossRef]

178. Vincent, J.; Mignot, G.; Chalmin, F.; Ladoire, S.; Bruchard, M.; Chevriaux, A.; Martin, F.; Apetoh, L.; Rebe, C.; Ghiringhelli, F. 5-Fluorouracil selectively kills tumor-associated myeloid-derived suppressor cells resulting in enhanced T cell-dependent antitumor immunity. Cancer Res. 2010, 70, 3052-3061. [CrossRef]

179. Alizadeh, D.; Trad, M.; Hanke, N.T.; Larmonier, C.B.; Janikashvili, N.; Bonnotte, B.; Katsanis, E.; Larmonier, N. Doxorubicin eliminates myeloid-derived suppressor cells and enhances the efficacy of adoptive T-cell transfer in breast cancer. Cancer Res. 2014, 74, 104-118. [CrossRef]

180. Germano, G.; Frapolli, R.; Belgiovine, C.; Anselmo, A.; Pesce, S.; Liguori, M.; Erba, E.; Uboldi, S.; Zucchetti, M.; Pasqualini, F.; et al. Role of macrophage targeting in the antitumor activity of trabectedin. Cancer Cell 2013, 23, 249-262. [CrossRef]

181. Xie, W.; Forveille, S.; Iribarren, K.; Sauvat, A.; Senovilla, L.; Wang, Y.; Humeau, J.; Perez-Lanzon, M.; Zhou, H.; Martinez-Leal, J.F.; et al. Lurbinectedin synergizes with immune checkpoint blockade to generate anticancer immunity. Oncoimmunology 2019, 8, e1656502. [CrossRef] [PubMed]

182. Arrieta, O.; Zatarain-Barron, Z.L.; Cardona, A.F. New opportunities in a challenging disease: Lurbinectedin for relapsed small-cell lung cancer. Lancet Oncol. 2020, 21, 605-607. [CrossRef]

183. Diel, I.J.; Solomayer, E.F.; Costa, S.D.; Gollan, C.; Goerner, R.; Wallwiener, D.; Kaufmann, M.; Bastert, G. Reduction in new metastases in breast cancer with adjuvant clodronate treatment. N. Engl. J. Med. 1998, 339, 357-363. [CrossRef]

184. Cassetta, L.; Pollard, J.W. Targeting macrophages: Therapeutic approaches in cancer. Nat. Rev. Drug Discov. 2018, 17, 887-904. [CrossRef]

185. Javeed, A.; Ashraf, M.; Riaz, A.; Ghafoor, A.; Afzal, S.; Mukhtar, M.M. Paclitaxel and immune system. Eur. J. Pharm. Sci. 2009, 38, 283-290. [CrossRef] [PubMed]

186. Kodumudi, K.N.; Woan, K.; Gilvary, D.L.; Sahakian, E.; Wei, S.; Djeu, J.Y. A novel chemoimmunomodulating property of docetaxel: Suppression of myeloid-derived suppressor cells in tumor bearers. Clin. Cancer Res. Off. J. Am. Assoc. Cancer Res. 2010, 16, 4583-4594. [CrossRef]

187. Buhtoiarov, I.N.; Sondel, P.M.; Wigginton, J.M.; Buhtoiarova, T.N.; Yanke, E.M.; Mahvi, D.A.; Rakhmilevich, A.L. Anti-tumour synergy of cytotoxic chemotherapy and anti-CD40 plus CpG-ODN immunotherapy through repolarization of tumour-associated macrophages. Immunology 2011, 132, 226-239. [CrossRef] 
188. Wan, S.; Pestka, S.; Jubin, R.G.; Lyu, Y.L.; Tsai, Y.C.; Liu, L.F. Chemotherapeutics and radiation stimulate MHC class I expression through elevated interferon-beta signaling in breast cancer cells. PLOS ONE 2012, 7, e32542. [CrossRef]

189. Green, D.R.; Ferguson, T.; Zitvogel, L.; Kroemer, G. Immunogenic and tolerogenic cell death. Nat. Rev. Immunol. 2009, 9, 353-363. [CrossRef]

190. Schafer, Z.T.; Brugge, J.S. IL-6 involvement in epithelial cancers. J. Clin. Investig. 2007, 117, 3660-3663. [CrossRef]

191. Waugh, D.J.; Wilson, C. The interleukin-8 pathway in cancer. Clin. Cancer Res. Off. J. Am. Assoc. Cancer Res. 2008, 14, 6735-6741. [CrossRef] [PubMed]

192. Showalter, A.; Limaye, A.; Oyer, J.L.; Igarashi, R.; Kittipatarin, C.; Copik, A.J.; Khaled, A.R. Cytokines in immunogenic cell death: Applications for cancer immunotherapy. Cytokine 2017, 97, 123-132. [CrossRef] [PubMed]

193. Anderson, B.E.; McNiff, J.M.; Matte, C.; Athanasiadis, I.; Shlomchik, W.D.; Shlomchik, M.J. Recipient CD4+ T cells that survive irradiation regulate chronic graft-versus-host disease. Blood 2004, 104, 1565-1573. [CrossRef] [PubMed]

194. Qu, Y.; Jin, S.; Zhang, A.; Zhang, B.; Shi, X.; Wang, J.; Zhao, Y. Gamma-ray resistance of regulatory CD4+CD25+Foxp3+ T cells in mice. Radiat. Res. 2010, 173, 148-157. [CrossRef]

195. Muroyama, Y.; Nirschl, T.R.; Kochel, C.M.; Lopez-Bujanda, Z.; Theodros, D.; Mao, W.; Carrera-Haro, M.A.; Ghasemzadeh, A.; Marciscano, A.E.; Velarde, E.; et al. Stereotactic Radiotherapy Increases Functionally Suppressive Regulatory T Cells in the Tumor Microenvironment. Cancer Immunol. Res. 2017, 5, 992-1004. [CrossRef]

196. Belcaid, Z.; Phallen, J.A.; Zeng, J.; See, A.P.; Mathios, D.; Gottschalk, C.; Nicholas, S.; Kellett, M.; Ruzevick, J.; Jackson, C.; et al. Focal radiation therapy combined with 4-1BB activation and CTLA-4 blockade yields long-term survival and a protective antigen-specific memory response in a murine glioma model. PLoS ONE 2014, 9, e101764. [CrossRef]

197. Liao, C.; Xiao, W.; Zhu, N.; Liu, Z.; Yang, J.; Wang, Y.; Hong, M. Radiotherapy suppressed tumor-specific recruitment of regulator T cells via up-regulating microR-545 in Lewis lung carcinoma cells. Int. J. Clin. Exp. Pathol. 2015, 8, 2535-2544. 